\title{
Lower-Middle Devonian rugose coral faunas of Nevada: Contribution to an understanding of the "barren" E Zone and Choteč Event in the Great Basin
}

\author{
ALAN E.H. PEDDER
}

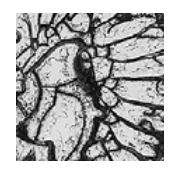

\begin{abstract}
The "lower Middle Devonian" part of a coral zonation proposed for the region in 1974 comprised in ascending order $\mathrm{D}_{2}$ and $\mathrm{D}_{3}$ subzones and a "barren" $\mathrm{E}$ zone. In terms of the conodont zonation currently employed in Nevada, the $\mathrm{D}_{2}$ subzone is Emsian gronbergi and inversus zones. The original stratigraphic definition of the $\mathrm{D}_{3}$ subzone places it in the upper Emsian serotinus Zone on Lone Mountain, whereas the coral index defining the zone has been collected subsequently only from Eifelian upper costatus Zone beds. The original stratigraphic definition of the "barren" E zone places it in a lower part of the costatus Zone, above an inferred depositional break. Thus, as defined on Lone Mountain, the $\mathrm{D}_{3}$ subzone is slightly younger than the E zone. These zones are not barren. Revised taxonomy and age determinations of previously described species, coupled with new data from the southern Sulphur Spring and northern Antelope ranges, have revealed four successive coral assemblages ranging from serotinus to costatus Zone age. Differences between the second and third of these assemblages are particularly significant, and may be considered to represent a local manifestation of the Choteč Event. A detailed review of the genus Synaptophyllum shows it to be an Emsian endemic in the Maghrebo-European Realm, not an early Eifelian endemic in the Eastern Americas Realm. New taxa comprise a family, one genus and two species. Romanophyllum paulyi gen. et sp. nov., which possibly represents one of the last vestiges of the Pragian-Emsian Great Basin coral province, is assigned to the Romanophyllidae fam. n. Xystriphyllum trojani sp. nov. is described as an example of one of earliest ptenophyllid species to return to the Great Basin after the absence of the family from the region since late Lochkovian time. $\bullet$ Key words: Nevada, Devonian, corals, biozones, Choteč Event.
\end{abstract}

PEDDER, A.E.H. 2010. Lower-Middle Devonian rugose coral faunas of Nevada: Contribution to an understanding of the "barren" E Zone and Choteč Event in the Great Basin. Bulletin of Geosciences 85(1), 1-26 (9 figures). Czech Geological Survey, Prague. ISSN 1214-1119. Manuscript received December 4, 2009; accepted in revised form February 12, 2010; published online March 15, 2010; issued March 22, 2010.

Alan E.H. Pedder, Geological Survey of Canada, Emeritus, 8859 Park Pacific Terrace, Sydney, British Columbia, CanadaV8L4S1; apedder@telus.net

C.W. Merriam devoted much of his working life to studies of the Middle Palaeozoic of the Great Basin, and in 1974 published a rugose coral biozonation for the Lower and Middle Devonian of the region. Seven Lower to middle Middle Devonian zones, informally designated $\mathrm{A}-\mathrm{G}$, were recognised. Following Subcommission on Devonian Stratigraphy (SDS) decisions and various conodont studies, the A-G coral zones are presently understood to range from Pragian to lower Givetian. Merriam's (1974, p. 21) short description of the Lower Middle Devonian E zone was based on its outcrop on Lone Mountain, where crinoidal carbonates of the zone are dolomitised, all but destroying their coral content. Although Merriam reported the presence of Disphyllum? and fragments having "characteristics of Cyathophyllum" in the zone, he also referred to it as the "barren zone".

In a review of Merriam's Silurian and Devonian zonations, Johnson \& Oliver (1977) repeated the earlier
Devonian E zone identifications and correlated the zone with Johnson's (1977) Faunal Interval 15 and the costatus conodont zone, but noted that there was no described coral to define the zone. The present paper establishes that the E zone was not barren. It will also show that the change from Lower to Middle Devonian coral faunas, which was concurrent with the demise of the Pragian-Emsian Nevada coral province (Pedder \& Murphy 2004), involved three steps, and that the middle of these corresponds closely to the Choteč Event of central Europe.

Special attention is given to the taxonomy, occurrences and apparent migrations of the long misunderstood and misidentified genus Synaptophyllum. Together with the return of the Ptenophyllidae to central Nevada, Synaptophyllum plays an important role in defining the three-step evolution of the "barren" E zone. 


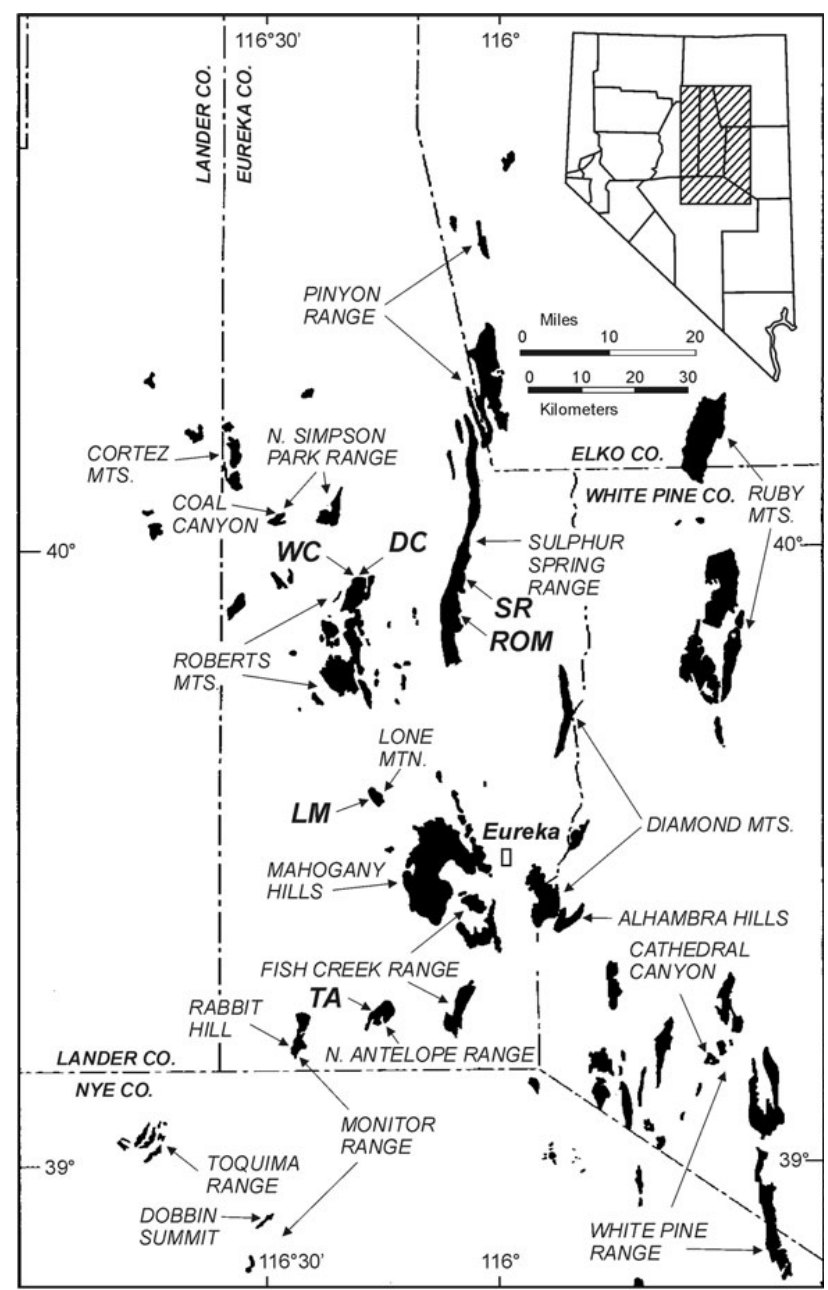

Figure 1. Map of central Nevada showing Devonian outcrop areas, county boundaries and locations pertinent to this work. $-\mathrm{DC}-$ site of MDC II Dry Creek section. • LM - site of type sections of Bartine and Coils Creek members, and Merriam's (1974) Lone Mountain reference section. • ROM - sites of ROM I-IV sections. • SR - site of Sadler Ranch Formation type section. • TA - sites of W.R. Trojan's northern Antelope TA II-Va sections. $\bullet$ WC - site of type section of Denay Formation, on Willow Creek.

\section{Lithostratigraphy}

Coral bearing lithologic units employed or mentioned in this work are: 1) Bartine Member; 2) Coils Creek Member; 3) Sadler Ranch Formation, undivided; 4) crinoidal unit of the Sadler Ranch Formation; 5) lower member of the Denay Formation.

The Bartine Member of the McColley Canyon Formation is used exactly as it was proposed by Murphy \& Gronberg (1977, p. 131). On Lone Mountain, it corresponds approximately to the lower 150 to $160 \mathrm{~m}$ of Merriam's (1974, p. 8) Unit 2 of the Nevada Formation. The Bartine Member is the main Emsian coral bearing unit in Nevada (Pedder \& Murphy 2004, p. 839) and was the most important source of corals used to define Merriam's
D zone, especially the $\mathrm{D}_{2}$ subzone. The type section on Lone Mountain is part of both Merriam's “Lone Mountain reference section" and E.C. Gronberg's FF section.

The type section of the Coils Creek Member of the McColley Canyon Formation is also on Lone Mountain (Murphy \& Gronberg 1977, p. 131), where it directly overlies the type Bartine Member outcrop and corresponds approximately to the upper 60 to $70 \mathrm{~m}$ of Merriam's Unit 2 of the Nevada Formation. As proposed, the member comprised two units, both 98 feet $(29.9 \mathrm{~m})$ thick. The entire lower unit is referred to the inversus conodont zone (Klapper \& D.B. Johnson in Klapper 1977, p. 42) and to Nevada Faunal Interval (FI) 13 (Johnson 1977, p. 22). No rugose coral is known from the lower unit on Lone Mountain. However, to the north in the Roberts Mountains, and to the south in Fish Creek Range, Breviphrentis invaginata (Stumm) is moderately common in some inversus Zone beds in the lower part of the member. Pedder \& Murphy (2004, p. 838) considered the "Bartine tongue", recognised by Kendall et al. (1983) in southern Sulphur Spring Range, to be a more argillaceous, less resistant facies of the Coils Creek Member. In the northern Antelope Range TA sections, Johnson et al. (1986) and Johnson et al. (1996) assigned about $32 \mathrm{~m}$ of section, between the disconformable base of a sandstone bed (tongue of Oxyoke Canyon Sandstone?) and the base of the Denay Formation, to the Coils Creek Limestone. This interval, which is given a thickness of $40 \mathrm{~m}$ in Morrow (2007, fig. 51), and which represents the entire Devonian T-R cycle Ic of Johnson et al. (1986), is currently referred to the Sadler Ranch Formation (Morrow 2007, p. 51).

The Sadler Ranch Formation was proposed by Kendall et al. (1983, p. 2200) for predominantly crinoidal dolostones exposed on the eastern flank of Sulphur Spring Range. As mapped by Kendall, it overlies a "tongue of Bartine Limestone member" and is overlain by the more widespread Sentinal Mountain Dolomite. Although the base of the formation may be as old as inversus Zone, most of the formation ranges from serotinus to costatus Zone. Johnson et al. (1996, p. 12) believed the Sadler Ranch/Sentinal Mountain contact to be coincident with the base of Devonian T-R cycle Id, and that no part of the Sadler Ranch Formation is as young as the lower Denay Limestone. An outcrop of variably crinoidal dolomite (ROM III section), which includes the type stratum of Synaptophyllum romanense, overlies a tongue of Oxyoke Canyon Sandstone and is separated by two high angle faults of small displacement from the Coils Creek Member (ROM I \& IV sections), is referred to the Sadler Ranch Formation.

Crinoidal packstones such as those illustrated from Lone Mountain (Johnson et al. 1968, text-fig. 4; Fig. 2 herein) and from northern Antelope Range (Fig. 3 herein) are widely distributed in the patulus (undivided) and 
costatus zones of central Nevada. Units in which crinoidal packstones of this age are especially characteristic, have been assigned to: 1) crinoidal member, middle Nevada Formation (Merriam 1940); 2) crinoidal unit or member, Telegraph Canyon Formation (Johnson et al. 1968, Murphy \& Gronberg 1970); 3) unit 3, Nevada Formation (Merriam 1974); 4) Denay Limestone (Johnson et al. 1980); 5) crinoidal member Union Mountain Formation (Klapper \& Johnson 1975, Kendall et al. 1983); 6) Coils Creek Limestone (Johnson et al. 1986); 7) upper Sadler Ranch Formation (Morrow 2007). In this paper, units of this kind on Lone Mountain and northern Antelope Range are referred to as crinoidal units of the Sadler Ranch Formation.

The Denay Formation was proposed by Johnson (1966, p. 154) for about $275 \mathrm{~m}$ (Murphy 1977, fig. 2) Middle Devonian strata, lying between the McColley Canyon and Devils Gate formations, on the eastern side of Willow Creek, northern Roberts Mountains. Debris flows with Xystriphyllum trojani sp. nov. and other allochthonous corals, occurring near the base of the formation in northern Antelope Range, are assigned to the lower member of the formation. The lower member has not been formally named, but has been recognised in the type section (Murphy, 1977) as well as in the northern Antelope Range (Johnson et al. 1980, 1988).

\section{Sub costatus Zone depositional breaks}

The postulated disconformity between what are presently known as the Coils Creek Member and overlying Denay Formation on the eastern side of Willow Creek, Roberts Mountains, was first outlined by Johnson (1962, pp. 543, 544). The same break was recognised in northern Sulphur Spring Range between the Sevy Dolomite and Union Mountain Sandstone. The initial estimate of the magnitude of the discomformity, reported by Johnson (1966, p. 153) as the interval between the pinyonensis and circula zones (FI 13-FI 15), was reduced when Murphy (1977, p. 191) noted that about 200 feet $(61 \mathrm{~m})$ of strata separate these zones, and that the uppermost beds below the break yield an Elythyna assemblage (lower FI 14). The apparent absence of patulus and partitus Zone conodonts is generally accepted as evidence of the same disconformity on Lone Mountain.

This is not, however, the situation in northern Antelope Range where beds above and below the base of the Denay Formation are costatus Zone age, and a questionable serotinus Zone break has been recognised lower in the succession (C.A. Sandberg in Morrow 2007, fig. 51). Winnowing and redeposition of crinoid ossicles in the partitus and lower costatus zones of northern Antelope Range must have resulted in very minor sedimentary breaks, but did not seriously affect preservation of the corals of these zones.
In contrast to the Roberts Mountains, there is no certain record of serotinus Zone benthos in northern Antelope Range.

\section{Emsian-Eifelian GSSP}

The Emsian-Eifelian Global Stratotype Section and Point (GSSP) is located at the lowest observed occurrence of $P o$ lygnathus partitus in the Wetteldorf trench section in the Eifel Hills, Germany (Ziegler \& Klapper 1985, p. 105; Ziegler 2000). Although this level has not been detected with certainty in any coral-bearing shelf sequence, operational estimates of the stratigraphic extent of the conodont zones - serotinus (upper Emsian), lower undivided patulus (uppermost Emsian), upper undivided patulus $(\approx$ partitus Subzone, lowermost Eifelian) and costatus (lower Eifelian) - are possible in Nevada.

\section{Choteč Event}

The appearance of Pinacites jugleri and other goniatites "a few layers" above the boundary between the Třebotov and overlying Choteč limestones in the Prague basin has been designated the jugleri Event (Walliser 1985, p. 403), and the boundary between the limestones themselves has been termed the Basal Choteč Event (Chlupáč \& Kukal 1986, p. 173). The incoming of Polygnathus partitus, which as far as can be determined is the base of the Middle Devonian, is $2.54 \mathrm{~m}$ below the top of the Třebotov Limestone in the Prastav quarry at Praha-Holyně (Klapper et al. 1978, fig. 1). The upper two of these three levels are commonly combined as the Choteč Event, and together are seen as a eustatic deepening event beginning at, or very close to the start of the Middle Devonian (base of partitus Subzone).

Disturbances to coral bearing biotopes during the Choteč Event brought considerable changes to rugosan faunas, and although the event was not a time of major extinction, it did result in an overall loss of rugosan genera. Never again was rugose coral provincialism to be as high as it had been in Emsian time.

\section{Coral biostratigraphy of the serotinus Zone}

The youngest unequivocal Lower Devonian coral assemblage in Nevada is the Breviphrentis magna assemblage in the serotinus Zone of the upper Coils Creek Member and lower Sadler Ranch Formation. A typical example from the Coils Creek Member of southern Sulphur Spring Range (sample 1998-25, Pedder \& Murphy 2004) includes Polygnathus serotinus, lies above occurrences of Polygnathus inversus lower in the member, and below an occurrence of 

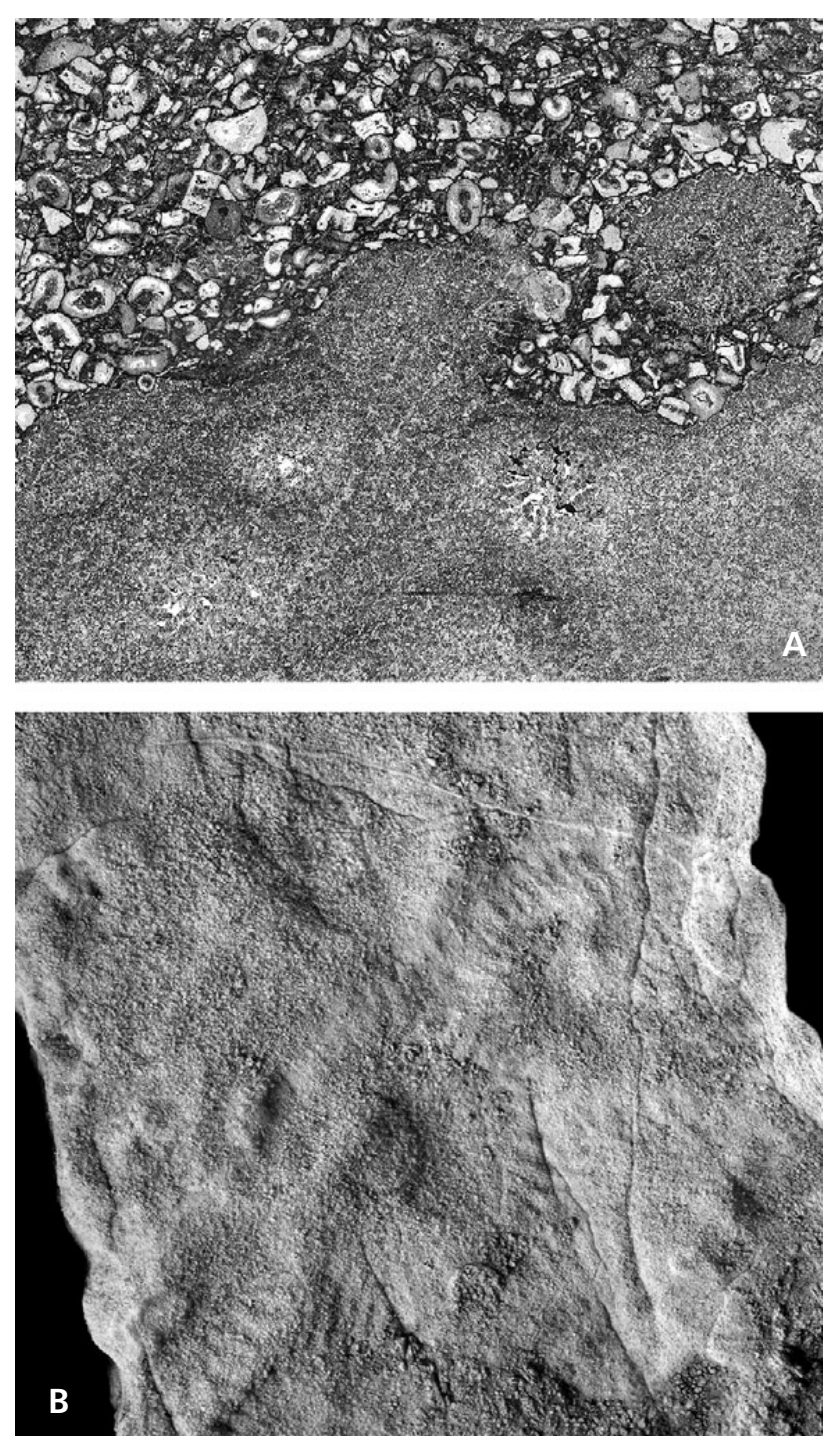

Figure 2. Dolomitised coral float, possibly Taimyrophyllum sp., in crinoidal grainstone, $\times 2.5$. Crinoidal unit, Sadler Ranch Formation, and Merriam's (1974) Zone E, in his Lone Mountain reference section. - A - thin section. $\bullet \mathrm{B}-$ hand specimen.

Polygnathus laticostatus higher in the same member (conodonts identified by M.A. Murphy).

Corals from the upper unit of the Coils Creek Member in northern Roberts Mountains, shown to the author by M.A. Murphy as examples of the horn corals mentioned in the original description of the member, are specimens of Breviphrentis magna (Stumm). Other species of the serotinus Zone and the lower FI 14 Breviphrentis magna fauna present in the northern Roberts Mountains include Eurekaphyllum sp., Stummelasma antelopense (Stumm), Pentamerella niebuhri Johnson \& Kendall, Carinagypa aseptata Johnson, Elythyna kingi Johnson and Panderinellina expansa Uyeno \& Mason (Murphy 1977, p. 192; Pedder 2002, p. 148).
The only species definitely assigned to the $\mathrm{D}_{3}$ subzone by Merriam (1974) was identified as Mesophyllum (Arcophyllum) kirki (Stumm), originally named Mesophylloides kirki by Stumm (1937, p. 441). Pedder \& McLean (1982, p. 75) regarded Stumm's species to be a nomen dubium and referred to Merriam's material as Mesophyllum kirki (Stumm, 1937) sensu Merriam, 1974. Using Merriam's measurements of his Lone Mountain reference section, Pedder \& McLean, and Johnson \& Oliver (1977, p. 1466) reasoned that Merriam's $\mathrm{D}_{3}$ Mesophyllum specimens came from the serotinus Zone in the Coils Creek Member. However, Merriam's specimens attributed to M. kirki came from more than $1 \mathrm{~km}$ northwest of the Lone Mountain reference section. In 1997, M.A. Murphy and the present author examined the Bartine and Coils Creek members on northwestern Lone Mountain (M-P I section) but were unable to recollect Merriam's M. kirki species. After many years of collecting in central Nevada, additional material comparable to M. kirki (Stumm) sensu Merriam has only been found as partly or wholly decorticated redeposited specimens in upper costatus Zone beds of northern Antelope Range. Breviphrentis magna is now considered the most appropriate coral index for the serotinus conodont zone and all but the lowest stata originally assigned to the $\mathrm{D}_{3}$ coral subzone.

Two other corals that Merriam (1974) thought may have come from his $\mathrm{D}_{3}$ subzone were identified as Dendrostella romanensis sp. nov. and Hexagonaria (Pinyonastraea) kirki (Stumm). The first is Synaptophyllum romanense from the undivided patulus Zone; the second (Merriam 1974, pl. 23, fig. 7 only) appears to be an unprepared specimen of an undescribed species of Pinyonastraea, known to the present author from the upper gronbergi Zone of the Bartine Member $\left(\mathrm{D}_{2}\right.$ subzone of Merriam).

\section{Coral biostratigraphy of the undivided patulus Zone}

Merriam (1974, p. 45) discovered the in situ occurrence of Synaptophyllum romanense in the ROM III section, but mentioned none of the other species occurring with it. He assigned it to either his $\mathrm{D}_{2}$ or $\mathrm{D}_{3}$ subzone and noted that it lies about 150 feet $(46 \mathrm{~m})$ stratigraphically above a large fauna including Breviphrentis sp. cf. invaginata. After careful examination of the section, it is clear that this fauna is the Breviphrentis magna assemblage of the author's 1998-25 collection, mentioned above. M.A. Murphy's measurement of the ROM I-III sections indicates that the two assemblages are separated by faults of small displacement and at least $49 \mathrm{~m}$ of strata.

The belief advocated here that the bed belongs to the patulus (undivided) Zone is based on its stratigraphic 

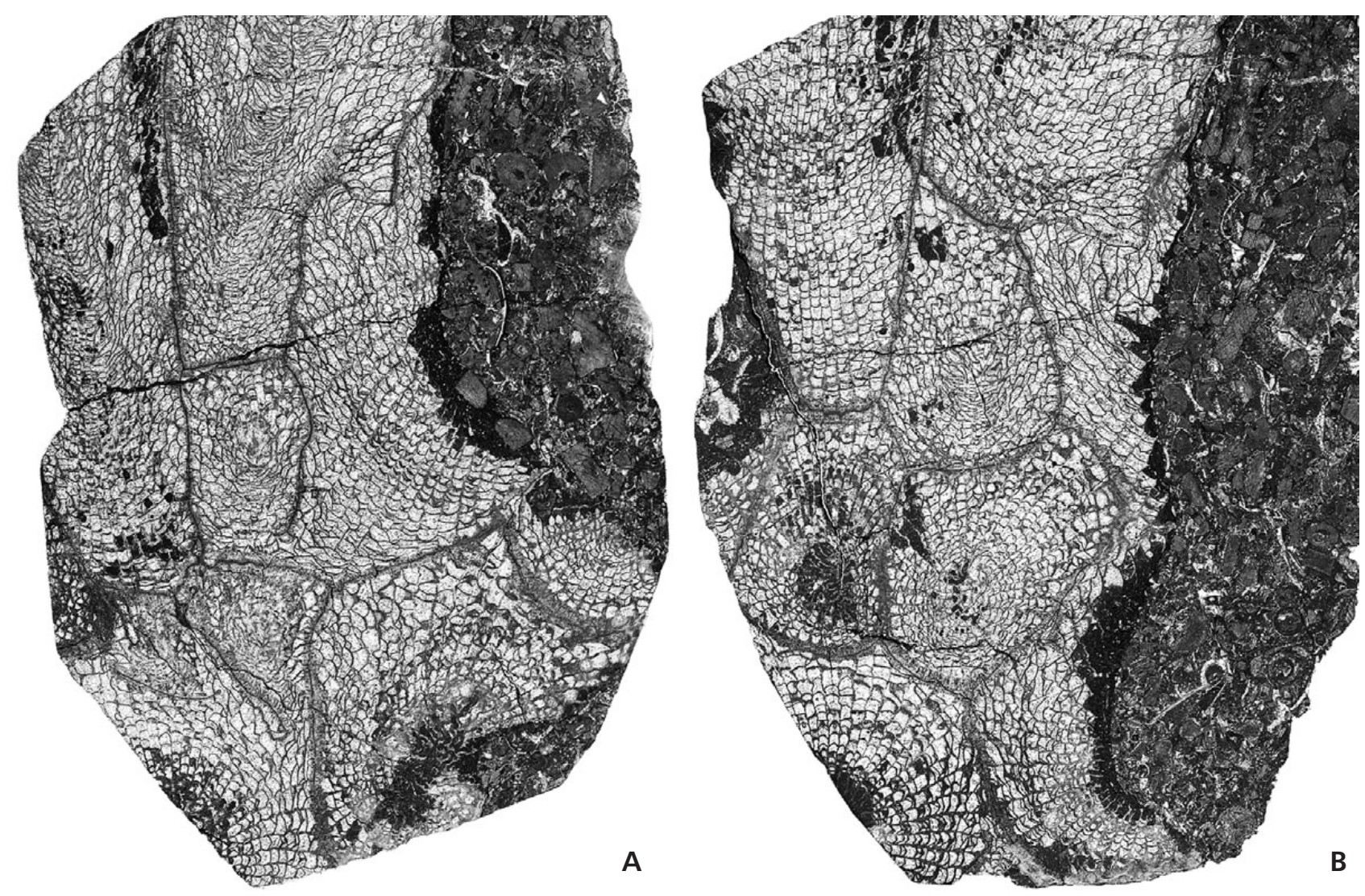

Figure 3. Reworked fragment of Xystriphyllum trojani sp. nov., partly enveloped by a dissolution surface, in lime grainstone. Crinoidal unit, Sadler Ranch Formation, northern Antelope Range, $\times 2.5$. USNM 539834 from 1996-31. • A - longitudinal thin section in upper part. • B - transverse thin sections in lower part.

position and coral fauna. The corals are quite distinct from those of the serotinus Zone, but include Synaptophyllum romanense, which occurs in the partitus Subzone and lower costatus Zone in northern Antelope Range. The single conodont species identified in the bed is Pandorinellina expansa. Other conodont data assembled by M.A. Murphy from the ROM III section are: 1) Polygnathus bultyncki occurs immediately below the bed; 2) Polygnathus bultyncki and P. cooperi occur immediately above the bed; 3) Pandorinellina expansa, which is not known to be younger than early costatus Zone, occurs as high as $13.2 \mathrm{~m}$ above the bed. The conodont data are consistent with a patulus Zone determination, but are not diagnostic of it.

Compared to the older Breviphrentis magna assemblage, the Synaptophyllum romanense assemblage is most notable for hosting the arrival in Nevada of the genus Synaptophyllum, and for its lack of breviphyllid corals, which dominate older upper Emsian faunas of the Great Basin (Pedder 2002). Romanophyllum paulyi gen. et sp. nov. and a large species of Nardophyllum are the only corals of the Synaptophyllum romanense assemblage that may have phylogenetic links to older Nevada species.

\section{Coral biostratigraphy of the partitus and lower costatus zones}

The lowest part of the crinoidal unit of the Sadler Ranch Formation (previously Coils Creek limestone) in northern Antelope Range (TA V section) is referred to the partitus Zone, while higher parts of the same unit belong to the lower costatus Zone (Klapper in Johnson et al. 1986). Many of the corals and presumably most of the crinoidal ossicles in the middle and upper parts of the same crinoidal unit are allochthonous, as shown in Fig. 3, and likely include individuals from the partitus Zone. Nevertheless, the rugosan fauna is almost entirely different from the Synaptophyllum romanense assemblage in the Romano Ranch area. Specimens of Synaptophyllum romanense from northern Antelope Range, on average are larger, have more septa and are not accompanied by species of Romanophyllum, Nardophyllum or other undescribed genera accompanying the species in the Romano Ranch area. The most emphatic difference, however, is the presence of genera unknown in older Nevada faunas, including Pseudomicroplasma?, Mesophyllum, Thryptophyllum, and especially the ptenophyllid genera Dohmophyllum, Taimyrophyllum (well 
preserved - not just the coral illustrated in Fig. 2) and Xystriphyllum.

\section{Coral biostratigraphy of the upper costatus and possibly lowermost australis zones}

Allochthonous brachiopods of the Pentamerella wintereri assemblage occur in upper costatus Zone debris flows in the basal $21 \mathrm{~m}$ of the Denay Formation in northern Antelope Range (Johnson et al. 1980, Johnson 1990). W.A. Oliver examined fragmentary silicified corals from the same beds, but among the Rugosa was only able to unquestionably identify three genera - Microplasma, Cystiphylloides and Metrionaxon (tables 2, 3 in Johnson et al. 1980). Although the Metrionaxon may have been autochthonous, the Microplasma and Cystiphylloides were likely allochthonous specimens of Pseudomicroplasma?, and Zonophyllum which are moderately common genera in these beds. Besides Pseudomicroplasma? and Zonophyllum, the author's collections include Mesophyllum sp. cf. M. kirki (Stumm) sensu Merriam, 1974, Taimyrophyllum sp., Xystriphyllum trojani sp. nov. and the earliest Nevada examples of the quintessentially Eifelian and pre-Taghanic Givetian genus Sociophyllum.

The lowest level of the costatus/australis zonal boundary in northern Antelope Range has been set below the first occurrence of Tortodus kockelianus australis, at the entry of Polygnathus parawebbi, $19.9 \mathrm{~m}$ above base of the Denay Formation (Klapper in Johnson et al. 1980, p. 92, table 16, collection 153). Two further rugosan genera occur close to this stratigraphic level in the same area. These are Exilifrons strict sense (revised since Pedder 1977) and Utaratuia. Their positions relative to the precise costatus/australis boundary have yet to be determined.

\section{Brachiopods of the "barren" E zone}

Three lower FI 14 brachiopod communities, named Leptocoelina (diverse), Elythyna and Alatiforme, have been demonstrated by Johnson (several papers, especially 1990). These were apparently so affected by the offshore shift in biotopes during the latest regressive stage of the T-R cycle Ib (Johnson et al. 1996), that very few brachiopods are known in central Nevada, and none has been described, from the entire T-R cycle Ic. Referring to this, Johnson (1990, p. 912) wrote that all three lower FI 14 communities "are succeeded upsection by beds barren of benthic invertebrates". This was an oversight, because Johnson et al. (1980, p. 79) had previously published the discovery of rare unsilicified brachiopods in the upper serotinus Zone and patulus Zone, which represent much of the middle and upper FI 14 in northern Antelope Range, and referred them collectively to the Warrenella fauna. The only brachiopods recovered by the author from beds of this age in central Nevada are fragments of atrypids and spiriferids from the Synaptophyllum romanense bed of patulus Zone age, in southern Sulphur Spring Range.

The first documented Eifelian brachiopod faunas to succeed the dearth of the phylum in central Nevada during the T-R cycle Ic of Johnson et al. (1996) are from Pentamerella wintereri bearing communities. These have been studied from at least six localities (Johnson et al. 1980, 1981; Johnson 1990). They are costatus Zone age (Klapper 1977 and elsewhere) and, on conodont-based correlations, are a zone above the partitus Subzone ptenophyllid corals of central Nevada. This indicates that the arrival in central Nevada of brachiopods of an Old World provincial affinity was later than the termination of the Pragian-Emsian Great Basin coral province (Pedder \& Murphy 2004), which occurred in two steps in patulus-partitus Subzones time.

\section{Trans-rheic and other migrations}

Regardless of whether the Rheic ocean floor persisted until late Palaeozoic time (Scotese \& McKerrow 1990, Scotese 1997, Golonka 2002), or was replaced by Middle Devonian time by other narrow ocean floor (Franke 1999, Azor et al. 2008), there is mounting palaeontological evidence from several benthic groups of Devonian migrations between the Maghrebo-European Realm (Plusquellec et al. 1997; Plusquellec 2007, p. 115) and the Eastern Americas Realm.

A detailed review of Synaptophyllum reveals an apparent Emsian origin for the genus in the Maghrebo-European Realm, followed by rapid latest Emsian-early Eifelian migrations of the genus to the EAR, to Nevada where it was one of the pioneer replacements of the Pragian-Emsian Great Basin coral province, and on to the Alxa (Alashan) massif. Further migration took the genus to the South China plate in later Eifelian time. Palaeobiogeographical significance of other Synaptophyllum occurrences in present day Asia cannot be assessed for lack of accurate age determinations and knowledge of plate tectonic setting. Nevertheless, it is interesting to recall that possible occurrences of the genus in East Junggar and Beishan, China, are from the same area as the Balkhash-Mongolia-Okhotsk province, which includes several Emsian EAR brachiopod genera (Hou \& Boucot 1990).

None of the few latest Emsian-earliest Eifelian ptenophyllid Rugosa recorded from the Magrebo-European Realm is likely to have been ancestral to any of the early Eifelian Ptenophyllidae of the Great Basin. And since there is no ptenophyllid of this age span in the EAR, the route taken by Dohmophyllum, Taimyrophyllum and Xystriphyllum to reach the Great Basin must have been different from the one travelled earlier by Synaptophyllum to 
arrive in the same area. Origins of the early Eifelian Nevada ptenophyllids and the cystimorph genera that accompany them will remain hidden at least until the fauna is described, but present speculation is that they may lie with elements of the latest Emsian Mount Podge fauna (Zhen 1995) preserved on the northeastern Australian craton.

\section{Systematic palaeontology}

Abbreviations used in this and subsequent parts of the work are: dc for corallite diameter; FI for Faunal Interval; GSC for Geological Survey of Canada; USNM for United States National Museum.

Family Stauriidae Milne Edwards \& Haime, 1850

\section{Genus Synaptophyllum Simpson, 1900}

1900 Synaptophyllum n.; Simpson, p. 212 in part (includes Acinophyllum McLaren, 1959).

1900 Placophyllum n.; Simpson, p. 216.

1959 Synaptophyllum Simpson, 1900. - McLaren, p. 16.

1976 Synaptophyllum Simpson. - Oliver, p. 46.

1981 Synaptophyllum Simpson, 1900. - Hill, p. F143 in part? (cited distribution probably includes Smithiphyllum Birenheide, 1962).

1995 Synaptophyllum Simpson, 1900. - Lin et al., p. 174.

Type species. - Diphyphyllum arundinaceum Billings, 1859, p. 134. Species revised by McLaren (1959, p. 18, pl. 7, pl. 8, figs 1a-5b, text-figs 2-6) and Oliver (1976, p. 47, pls 2-4, pl. 7, figs 7-11). The strata of the lectotype (chosen by McLaren 1959, p. 19) and fragmentary paralectotypes were originally given as Corniferous limestone. In current terms, all are believed to be from the Edgecliff Member of the Onondaga Limestone. The type locality is three miles $(4.8 \mathrm{~km})$ west of Cayuga, southwestern Ontario. Paralectotypes are from Wainfleet township, Welland County, and Walpole township, Haldimand County, in the same general region of southern Ontario. When McLaren (1959, caption pl. 7) recorded the type stratum as the Bois Blanc Formation, he was following Best (1953), who, in applying much of the Michigan stratigraphic nomenclature in southwestern Ontario, employed the term Bois Blanc in a much wider sense than it is currently used in the province (Uyeno et al. 1982).

Type species of Placophyllum. - P. tabulatum Simpson, 1900 , p. 216, text-fig. 41. Species discussed briefly by Lang et al. (1940, p. 100) and Stumm (1949, p. 30), and more fully by McLaren (1959, p. 17) and Oliver (1976, p. 49). Two of three now extant original sections were figured by McLaren (1959, pl. 10, figs 1, 2) as syntypes. Oliver (1976, pl. 5, figs 1-3) illustrated all three sections as the holotype. The type occurrence is in the Onondaga Limestone, Walpole township, Haldimand County, southwestern Ontario, and is almost certainly in the Edgecliff Member.

Other species. - Dendrostella romanensis Merriam, 1974, redescribed herein, Synaptophyllum kladion Oliver, 1976 (p. 50, pl. 6; pl. 7, figs 1-6), Heterophrentis minor Wang, 1978, Synaptophyllum multiseptatum Soto, 1981 (p. 93, figs 3.1a-5.5), Synaptophyllum dangchangense Liao \& Li, 1991 (pp. 603, 613, pl. 1, fig. 1a, b), and probably Nalivkinella angustitabulata Altevogt, 1968.

Synaptophyllum minus (Wang Zhiping in Kong \& Huang, 1978, p. 49, pl. 15, fig. 7a-c), from the Longdongshui Member of the Houershan Formation, southern Guizhou, China, was first described as a species of Heterophrentis Billings (1875?, p. 235). However, it is a fasciculate coral with typical Synaptophyllum corallites, which in no way resemble the solitary trochoid lectotype (Oliver 1993, pl. 1, figs 1, 2; pl. 2, fig. 2) of the type species of Heterophrentis.

Synaptophyllum(?) angustitabulatum (Altevogt, 1968, p. 758, pl. 1, figs 1a-2a) is based on fragmentary cylindrical corallites having the internal morphology of Synaptophyllum. Three of the five types, including the holotype, show intracalicular budding, suggesting that the morphology of a complete corallum would also be consistent with an assignment to Synaptophyllum. The types come from Radig's (1962, p. 256) Basiskalke between Aguión and Sibares, on the Cantabrian coast of Spain. Radig's Basiskalke (basal Couvinian limestone of Altevogt) was specifically included in the Moniello Formation in the formal definition of the formation (Arbizu et al. 1979, p. 105).

Diagnosis. - See Oliver (1976, p. 46) and Hill (1981, p. F143), but note that in both Synaptophyllum kladion Oliver and $S$. romanense (Merriam) tabulae are locally depressed.

Discussion. - Simpson erected Synaptophyllum for species which had been assigned to Eridophyllum Milne Edwards \& Haime (1850, p. lxxi), but in his view should not be included in that genus because of differences in radiciform processes (those of Eridophyllum do not penetrate the interior of adjacent corallites). Simpson was aware that Diphyphyllum Lonsdale (1845, p. 624), which Billings (1859) had used for some of these corals, is an unrelated Carboniferous genus. Confusion first arose because, although Simpson made Diphyphyllum arundinaceum the type species of Synaptophyllum, his description of the interior of the new genus, which mentioned the presence of dissepiments and septal carinae, was based entirely on species currently assigned to Acinophyllum McLaren (1959, p. 22). The problem stemming from Simpson's misleading description of 
Synaptophyllum was aggravated when Lang \& Smith (1935, p. 561, figs 19, 20), unable to discover the whereabouts of Billing's original material, mistakenly illustrated sections of an Upper Devonian coral from western Canada as a typical example of Synaptophyllum arundinaceum. The stylized figures of the western Canadian coral show a pipe of horseshoe dissepiments and phillipsastreid-like trabeculae, and were the basis for the widely held belief (Schouppé 1949, p. 124; Stumm 1949, p. 32; Wang Hongzhen 1950, p. 219; Różkowska 1953, p. 16; Hill 1956, p. F280; Soshkina in Soshkina et al. 1962, p. 308) that these were two of the diagnostic features of Synaptophyllum. McLaren's 1959 work published the discovery of at least some of Billing's specimens of Synaptophyllum arundinaceum, and demonstrated the characteristic tabular morphology of the species, as well as the absence of dissepiments and carinae from it, and is the foundation of the correct understanding of the genus.

Occurrences. - The earliest known are occurrences of $S y$ naptophyllum multiseptatum in the upper La Vid Group in the southern part of the Cantabrian zone of northwestern Spain, and occurrences of several species (Soto in Arbizu et al. 1979, p. 109), including S. multiseptatum, in the Middle Moniello Formation, in the northern part of the zone. All are likely to be serotinus Zone age (Keller \& Grötsch 1990, fig. 9; García-López \& Sanz-López 2002).

The earliest occurrences of Synaptophyllum in the Eastern Americas Realm (EAR) are those of $S$. arundinaceum, S. kladion and S. tabulatum in the Edgecliff Member of the Onondaga Limestone in New York State and the Niagara Peninsula of Ontario. S. arundinaceum is also present at a comparable (Oliver 1976), or questionably slightly higher (Ver Straeten 2007, fig. 8) level in the uppermost Bellepoint Member of the Columbus Limestone of Ohio. Other possible early EAR occurrences of the genus are in the Formosa reef limestones of the Amherstburg Formation, about $200 \mathrm{~km}$ northwest of the Niagara Peninsula occurrences of Synaptophyllum. These include the poorly preserved fragmentary corallites tentatively identified as Placophyllum and Depasophyllum by Fagerstrom (1961, pl. 4, figs 12-15). Klapper \& Oliver (1995, fig. 1) favoured a partitus Subzone and possibly uppermost patulus Subzone age for the Edgecliff Member of the Onodaga Limestone, whereas Prosch (1995) argued for an entirely late Emsian (serotinus Zone) age for the member. All the early EAR Synaptophyllum material is from Icriodus conodont biofacies and, as cautioned by Kirchgasser et al. (1985, p. 236), on inference only is assigned to the original undivided patulus Zone. Synaptophyllum kladion, known from one or two specimens from the upper part of the Edgecliff Member in Ontario and a few others from the costatus Zone in the Moorehouse Member of Niagara Peninsula and western New York, is the youngest certain EAR species of Synaptophyllum. An upper Eifelian specimen identified as Placophyllum? sp., from the Dundee Limestone near the northern end of the southern Michigan Peninsula, has been illustrated in an unprepared condition (Ehlers \& Kesling 1970, pl. 9, fig. 10), and should only questionably be referred to Synaptophyllum.

See under Synaptophyllum romanense (Merriam), for occurrences of the genus in Nevada.

A lower Eifelian coral from the lower Yikewusu Formation (in, or slightly above beds with costatus Zone conodonts) in the Zhusilenghaierhan area on the Alxa massive, western Inner Mongolia, was identified as Synaptophyllum kladion Oliver by Li Minglu (1987, p. 70, pl. 1, fig. 2a, b). Li described the coral as fasciculate and illustrated a short corallite with a diameter of $18 \mathrm{~mm}, 31$ major septa and sharply peripherally downturned tabulae. However, the types of S. kladion have a maximum dc of $6.9 \mathrm{~mm}$, a maximum of 20 major septa, and irregular tabulae, including some that are flat, undulating or even depressed. Although the Alxa massif coral is not S. kladion, the determination is consistent with current concepts of the genus Synaptophyllum. Synaptophyllum sp. has also been reported from what may be higher beds of the Yikewusu Formation near Wotuashan, in the same Zhusilenghaierhan region (Wang Xunlian \& Wang Hongzhen 1987, p. 312, table 2; Wang Xunlian 1987, p. 94). The fauna which includes this undescribed species of Synaptophyllum? comprises the Grypophyllum denckmanni-Acanthophyllum difficile Assemblage. Wang Xunlian \& Wang Hongzhen identified several Givetian corals in this assemblage, and were unequivocal concerning its Givetian age. But, other authors have taken the occurrence of a Kayseria lens- and possible Reticulariopsis-bearing brachiopod fauna in the top unit of the Yikewusu Formation (Zhang Yan 1985; Talent et al. 2001, p. 104, fig. 6) as evidence of an Eifelian age for the entire formation.

The only published occurrence of Synaptophyllum on the South China plate is that of S. minus in Guizhou Province. The species is part of the Utaratuia-Sociophyllum Assemblage Zone of the Longdongshui Formation (or Member of the Houershan Formation), which has been correlated with the middle to upper Eifelian (australis and kockelianus zones) Hume Formation of northwestern Canada (Liao 2003, pp. 419, 423).

Figure 4. Synaptophyllum romanense (Merriam), topotypes from Sadler Ranch Formation, 1990-31 locality, $\times 3$. $・$ A - USNM 539802, longitudinal section. • B, C - USNM 539803, longitudinal sections. • D - USNM 539802, longitudinal section. • E - USNM 539801, transverse section. • F - USNM 539800, transverse section. 


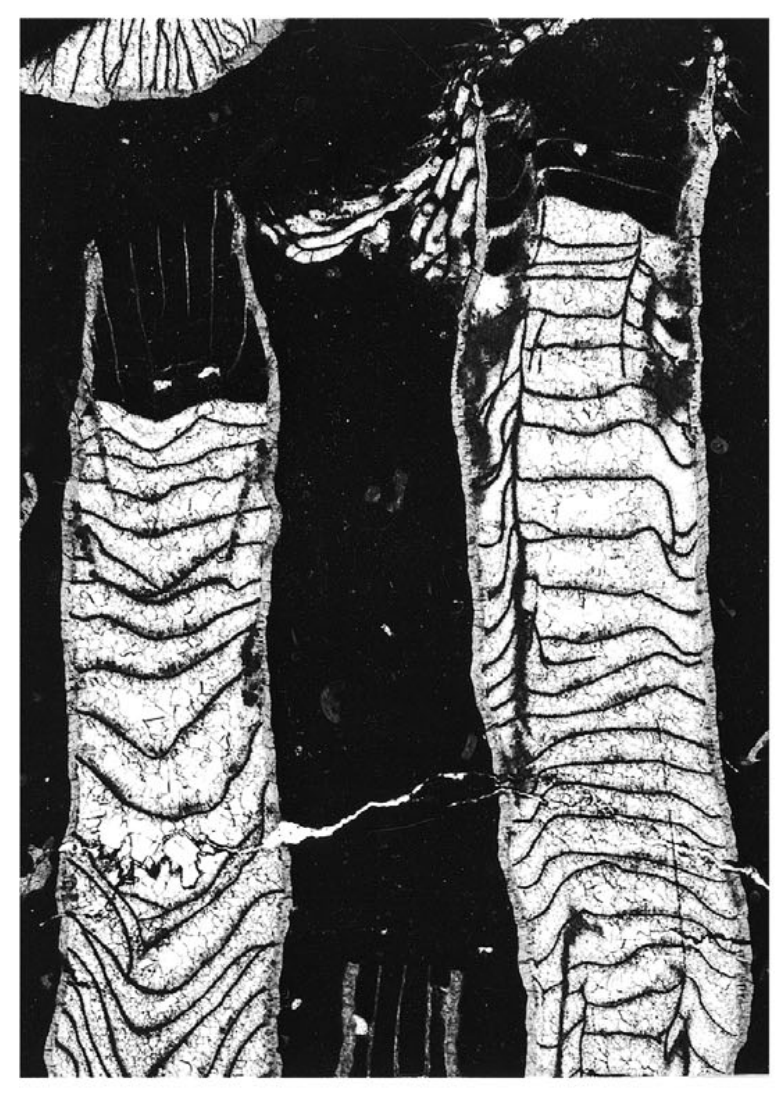

Alan E.H. Pedder • Lower-Middle Devonian rugose coral faunas of Nevada
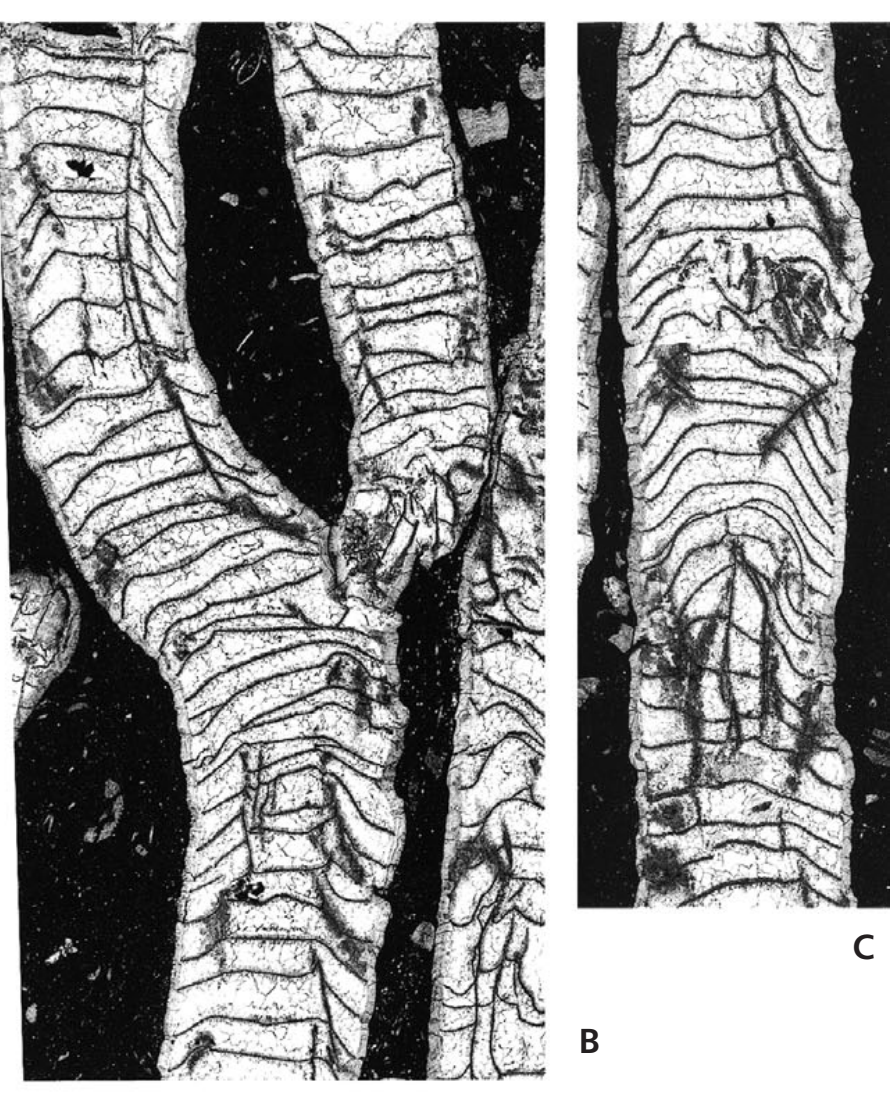

A
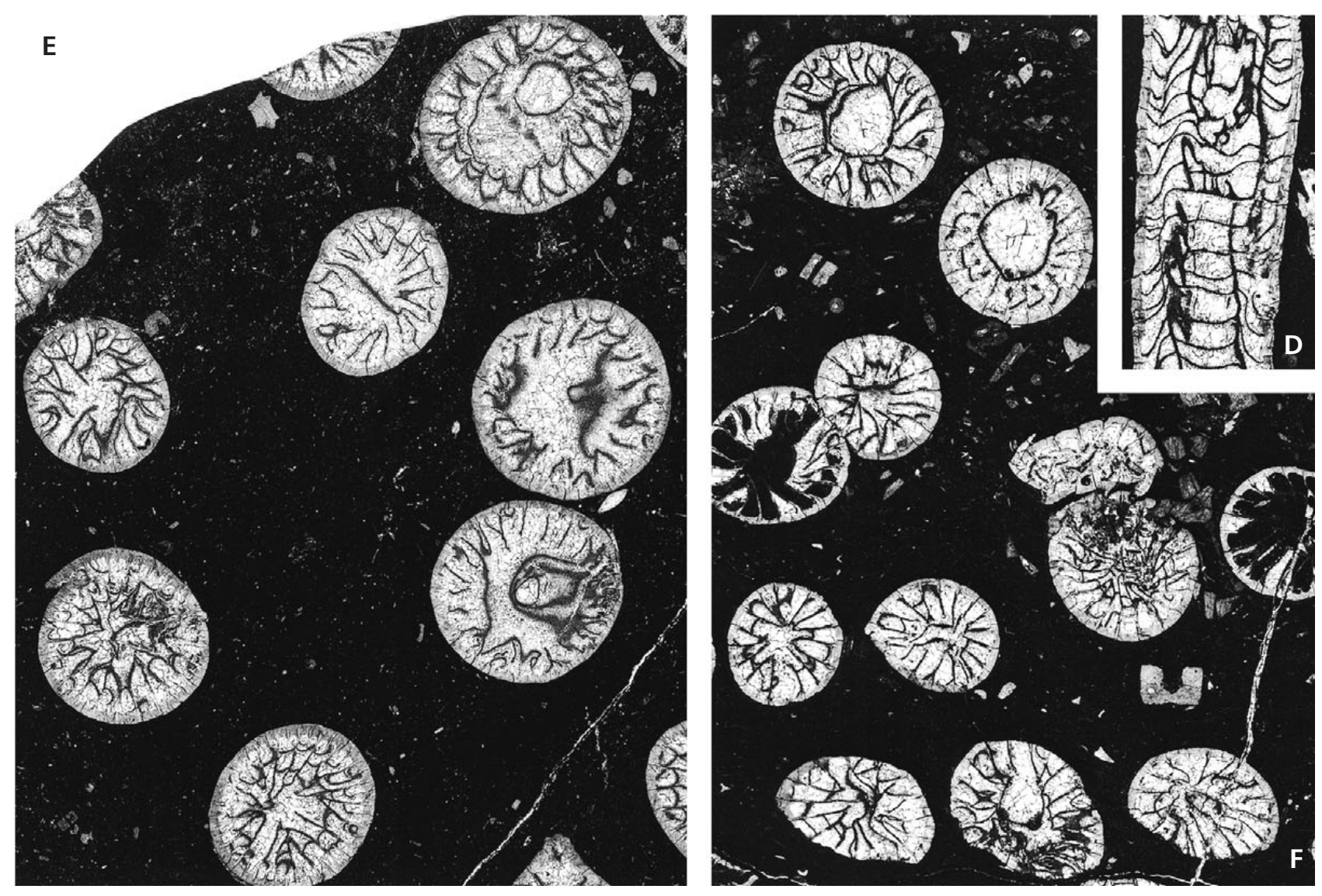
Possibly the youngest, and the youngest named species of Synaptophyllum is S. dangchangense Liao \& Li from the Middle Devonian Xihanshui Group in the northern Qinling fold belt, China. Although not precisely dated, other Rugosa of the Xihanshui Group are Givetian.

Wang Zhiping (1985, p. 68) listed Synaptophyllum in a combined list of "Yingtang age" ( $\approx$ Eifelian) genera from the Beitashan Formation in East Junggar and the Que'ershan Group of the Beishan Mountains area in northwestern Gansu Province, China.

\section{Synaptophyllum romanense (Merriam, 1974) comb. nov.}

Figures 4A-F, 5A, B, D-N

1974 Dendrostella romanensis n.; Merriam, p. 45, pl. 18, figs $1-4$.

1977 Dendrostella romanensis Merriam. - Johnson \& Oliver, p. 1466.

Type. - Holotype, USNM 159318. Type stratum and locality given as Nevada Formation, unit 2, Devonian coral zone $\mathrm{D}$, probably coral zone $\mathrm{D}_{2}$, but "may be in coral zone $\mathrm{D}_{3}$ ", at USGS locality M1031, northwest of Romano Ranch, Sulphur Spring Range, Nevada. This is the same as localities 1990-31, 1996-5, 1998-27 and 1999-11 of Appendix 2. No additional material was mentioned by Merriam.

Other material. - Seven topotypes: USNM 539800-539803 from 1990-31, USNM 539804, 539805 from 1998-27, and USNM 539806 from 1999-11. Nine other specimens: USNM 539807-539811 from 1994-8, USNM 539812, 539813 from 1996-32, and USNM 539814, 539815 from 1996-33.

Description. - Corallum fasciculate, phaceloid to dendroid. Spacing and curvature of corallites variable; axes of adjacent corallites generally less than $20 \mathrm{~mm}$ apart. Maximum height of corallum $>150 \mathrm{~mm}$; maximum width of corallum $>200 \mathrm{~mm}$. Diameter of adult corallites $6.5-8.2 \mathrm{~mm}$. Offsets generated by nonparricidal lateral budding (Fig. 4B), and apparently also by parricidal, intracalicular (axial) budding (Fig. 5A). Exterior surfaces unexposed in available material; fine septal furrows and interseptal furrows, mentioned in the original description of the species, not discernible in transverse sections. Calice cylindrical, with sharp distal rim, vertical wall and variable base. Depth of calice $>8 \mathrm{~mm}$.

Width of corallite wall $0.18-0.5 \mathrm{~mm}$. Wall embeds unexpanded septal bases. Septal arrangement imperfectly radial. Although width of spaces between septa is inconsistent in some corallites, there is no fossula or obvious cardinal-counter plane. Septa in two orders, both variable within a single corallum. Shortest of the major septa extend less than one-third of the distance to the axis. Longest major septa are as long as the radius of the lumen, but normally curve away from the axis. Minor septa locally entirely suppressed. Where present, their length is typically much shorter than that of the major septa; few minor septa exceed $0.3 \mathrm{~mm}$ in length. In the holotype and six of seven other specimens from the type stratum and locality, the adult dc is $6.6-8 \mathrm{~mm}$ and the number of major septa per adult corallite is consistently 20 . In the seventh topotype (USNM 539801), the maximum dc is $8.2 \mathrm{~mm}$ and the number of major septa per corallite 23 .

No dissepiment present in any of 36 longitudinal sections studied. Tabulae broad, mostly complete. Tabular morphology especially variable, even within corallites of a single corallum (Fig. 4A). Tabulae commonly flat to slightly concave over a wide periaxial area, and sharply downturned around periphery of corallite. Other tabulae may be more or less flat, or only gently concave or convex; a few may form distinctly depressed tabularial surfaces. Spacing of tabulae in periaxial region, 7-19, mostly 9 or 10 tabulae over a vertical distance of $10 \mathrm{~mm}$.

Discussion. - Dendrostella Glinski (1957, p. 87) is distinguished from Synaptophyllum by its characteristic septal bases. This diagnostic feature is not evident in the silhouette illustrations of the genus given in both the Kansas (Hill 1981, fig. 71.1b) and Beijing (Lin et al. 1995, fig. 337) treatises, but is shown well in Glinski's (1957) figure 14. As comparison of Fig. 5B with Oliver's (1976, pl. 4) figure 5 shows, the fine structure of the walls in Synaptophyllum romanense and Synaptophyllum arundinaceum are identical, and different from that of Dendrostella (Fig. 5C herein).

The description given above is based on the holotype and seven topotypes. Younger partitus-lower costatus specimens from northern Antelope Range are from a higher energy facies, and as a result, many are fragmentary. They are larger (dc commonly 8-8.5 mm; maximum $9.4 \mathrm{~mm}$ ), and have more septa (commonly $22 \times 2$; maximum $25 \times 2$ ).

Figure 5. Synaptophyllum romanense (Merriam) from Sadler Ranch Formation (A, B, D-N), and Dendrostella sp. from Blue Fiord Formation, Arctic Canada (C). • A - USNM 539803, topotype, × 3. • B - USNM 539801, topotype, $\times 10$. $・$ C - GSC 133059 from GSC Locality 26441 , $\times 9$. $\bullet$ D, F, H - USNM 539813 from 1996-32, ×3.・E, J - USNM 539811 from 1994-8, ×3.・ G, L - USNM 539812 from 1996-32, ×3.・I, M - USNM 539814 from 1996-33, $\times 3$. Bottom left transverse section (M) is from same corallite as longitudinal section (I); top left section (I) is oblique section of Pseudomicroplasma? sp. • K - USNM 539815 from 1996-33, × 3. • N - USNM 539807 from 1994-8, ×3. 

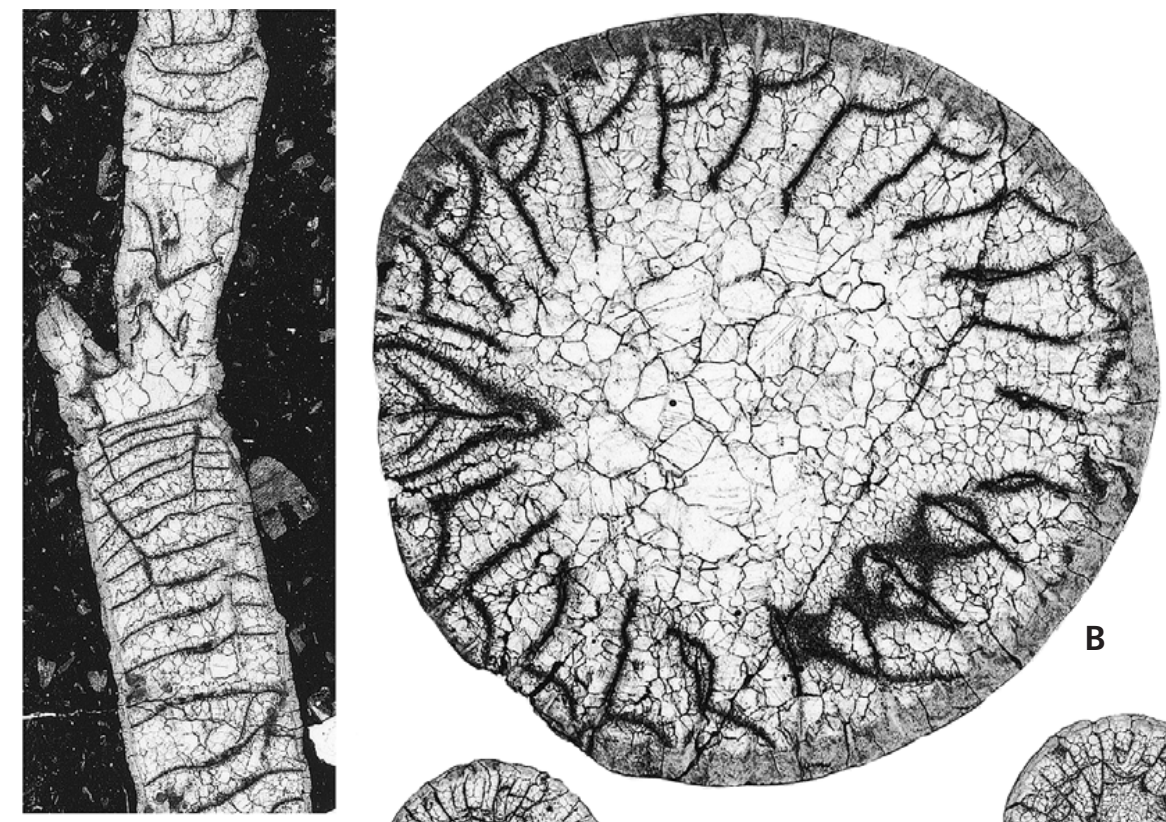

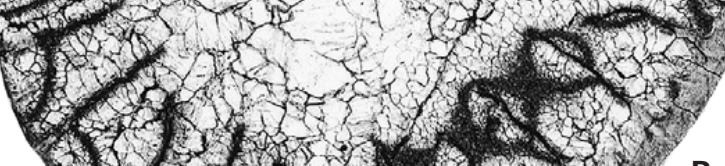

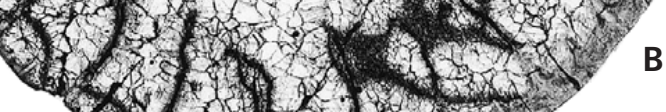

Qristing

TIIO

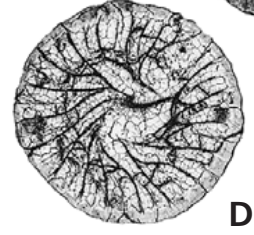

$\frac{1}{3}$

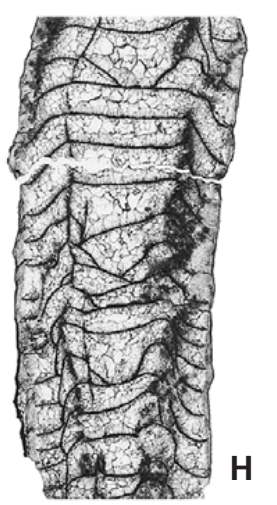

A
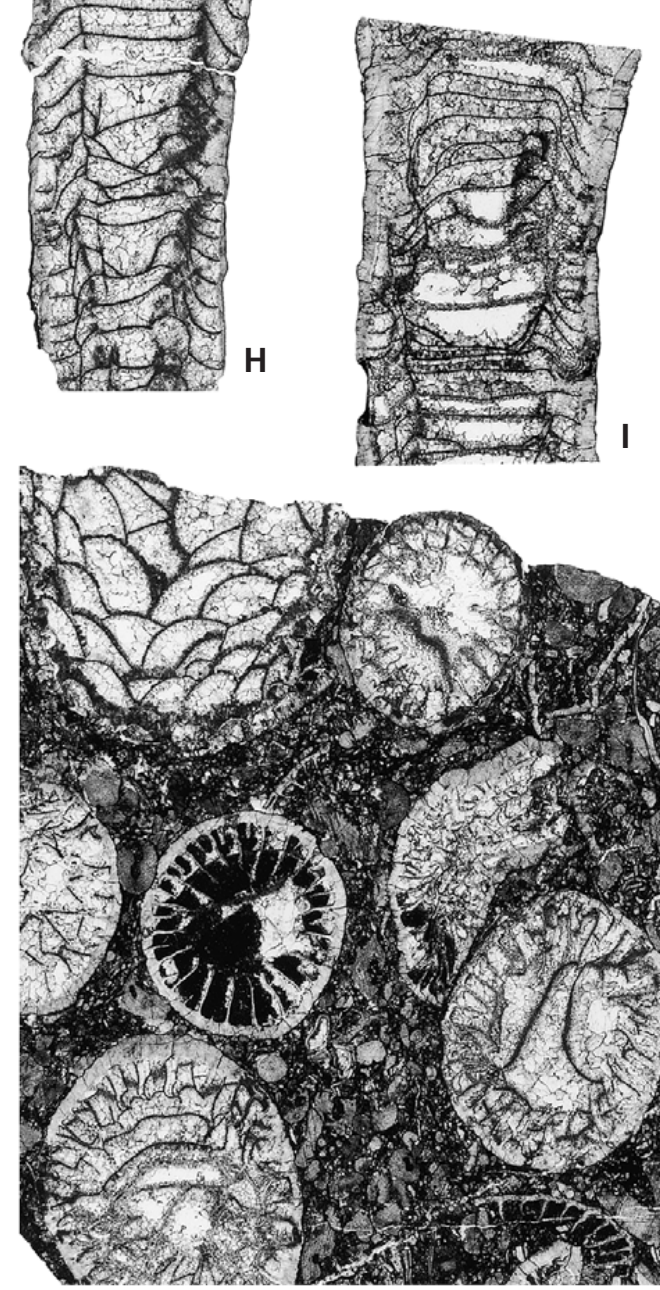

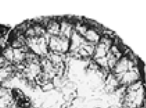
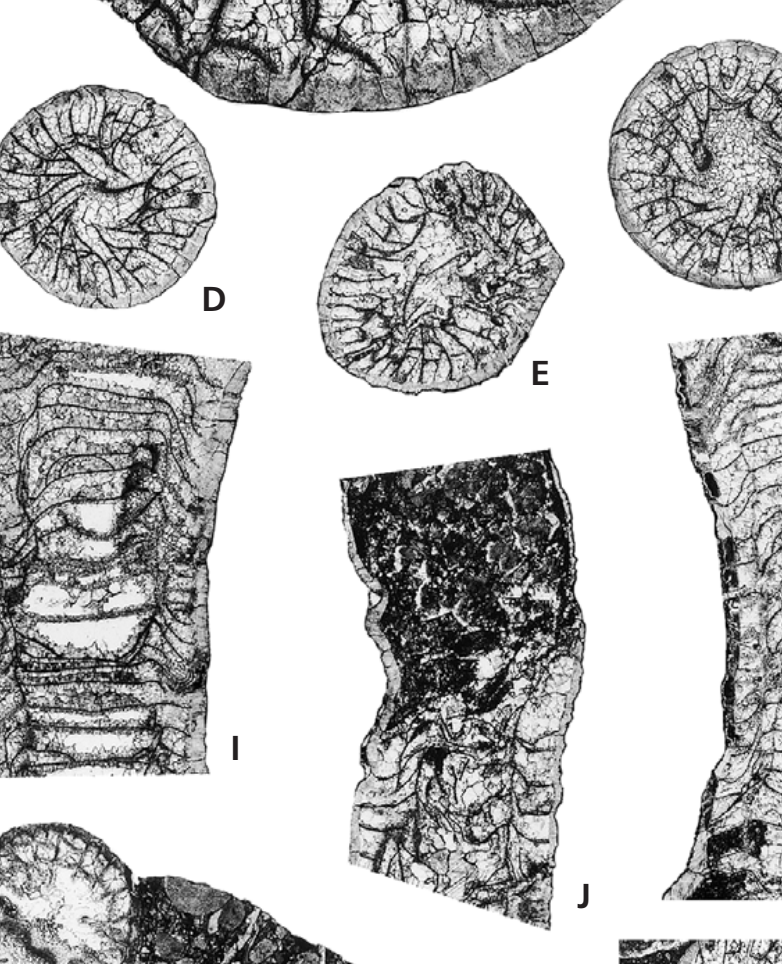

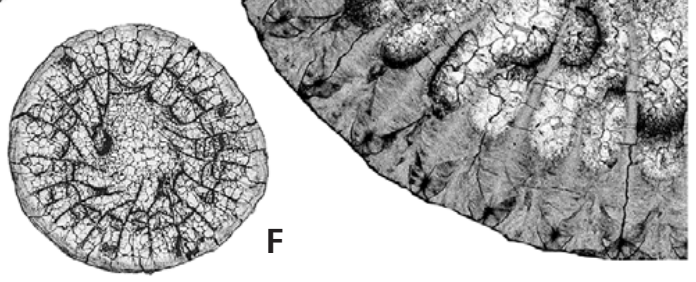
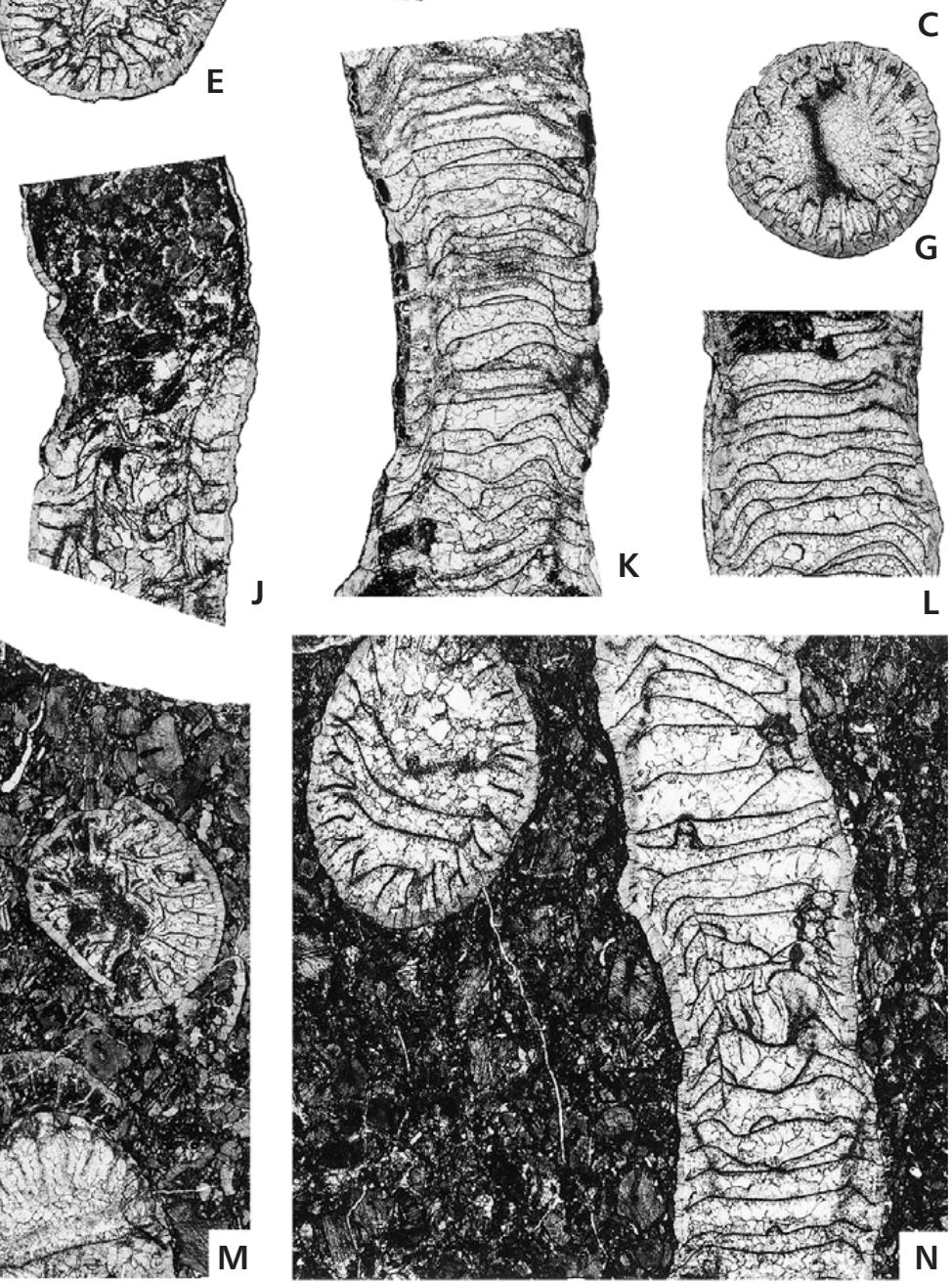
Also, their minor septa are, on the whole, longer, and their tabulae less variable (more typical of the genus Synaptophyllum).

Of the two or three species of Synaptophyllum named before $S$. romanense was established, S. arundinaceum most resembles the Nevada species. The mean dc and mean number of major septa are slightly larger in $S$. romanense. The principal difference, however, is in the tabularium. In $S$. romanense the major septa are infrequently and only locally amplexoid, and the tabulae are much less consistently typical of the genus.

Occurrence. - Uppermost Emsian or lowermost Eifelian, undivided patulus Zone, Sadler Ranch Formation, southern Sulphur Spring Range. Lower Eifelian, partitus Subzone and lower costatus Zone, Sadler Ranch Formation, northern Antelope Range.

Family Romanophyllidae nov.

Type genus. - Romanophyllum nov., a cryptogenic genus.

Diagnosis. - As for Romanophyllum, the only genus named to the family.

Remarks. - At maturity, corals of this family have transverse sections resembling those of the Kyphophyllidae Wedekind (as broadly interpreted by McLean \& Pedder 1987 and Sorauf 1998), whereas the longitudinal sections show the combined tabularial-dissepimentarial surfaces, and therefore also the calice, to be similar to cystimorph septal cones.

\section{Genus Romanophyllum nov.}

Type species. - Romanophyllum paulyi sp. nov.

Other species. - None named. One possible, older and unnamed species form the Emsian Bartine Member of Nevada.

Diagnosis. - Solitary rugose coral. Peripheral wall septothecate without periodic calicinal extensions, or other external indications of rejuvenescences. Cardinal septum and bilateral arrangement of septa prominent in early stages. Septa variously bent but not carinate, complete in early stages, and in all but the earliest stages, withdrawn from axis. Major septa commonly based on wide, steeply inclined presepiments in late stages. Sclerenchymal investment of septa and the steeply inclined dissepimentarial-tabularial surfaces thick in early to middle stages.

Etymology. - Romano Ranch and Greek phyllon meaning leaf, in Latin form.

Discussion. - Transverse sections of adult specimens of Romanophyllum resemble those of kyphophyllid corals, such as Tabulophyllum Fenton \& Fenton, 1924, which has been well illustrated by Sorauf (1998, pls 6-20) and fully discussed by McLean (2007, p. 17), but the deep inversely conical tabularial surfaces of Romanophyllum distinguish the genera in longitudinal section. There is some resemblance between Romanophyllum and the solitary kakisaphyllinid coral Dialeptophyllum Pedder (1990, p. 64). However, the tabularium in Dialeptophyllum is not conical, or as depressed. Furthermore, the prominent cardinal cardinal septum, strong bilateral septal symmetry and thick sclerenchyme of the early stages of Romanophyllum are not present in Dialeptophyllum.

A single specimen (USNM 539830) from the upper Bartine Member on Lone Mountain is questionably identified and illustrated (Fig. 8F, H, J) as a species of Romanophyllum. Its much fractured tabularium and missing proximal region prevent firm identification. One of the other two corals (USNM 510051) illustrated in Fig. 8 was previously (Pedder 2002, p. 145) considered to be an atypical species of Breviphyllum with a depressed tabularium. Since then, another specimen (USNM 53983; Fig. 8A, E, G) of the same Bartine Member species has been prepared. The species cannot be identified certainly with any known Nevada coral genus. The phylogeny of Romanophyllum is unknown, but if the problematic phylogeny of Romanophyllum is with the Breviphyllidae, it might be through atypical breviphyllid corals such as these.

\section{Romanophyllum paulyi sp. nov.} Figures 6A-L, 7A-R

Type series. - Holotype, USNM 539816 from 1998-27. Thirteen topotypic paratypes, USNM 539817-539829. Sadler Ranch Formation, lower Eifelian, costatus Zone; ROM III section, eastern foot of southern Sulphur Spring Range. See 1990-31 and identical localities in Appendix 2.

Description. - Corallum solitary, ceratoid to trochoid. Available specimens lack proximal tip and adult calice. Nevertheless, calice would clearly be subconical and lack

Figure 6. Romanophyllum paulyi gen. et sp. nov. Holotype (E, F, I) and paratypes from Sadler Ranch Formation. • A - USNM 539826 from 1998-27, $\times 2$ • B - USNM 539825 from 1998-27, ×2. • C - USNM 539827 from 1998-27, ×2. • D, H - USNM 539828 from 1999-11, × 2. • E, F, I - USNM 53986 from 1998-27, × 2. $\bullet$ G, J - USNM 539829 from 1999-11, × 2. $\bullet$ - part of USNM 539829 transverse section, from 1999-11, $\times 5$. 

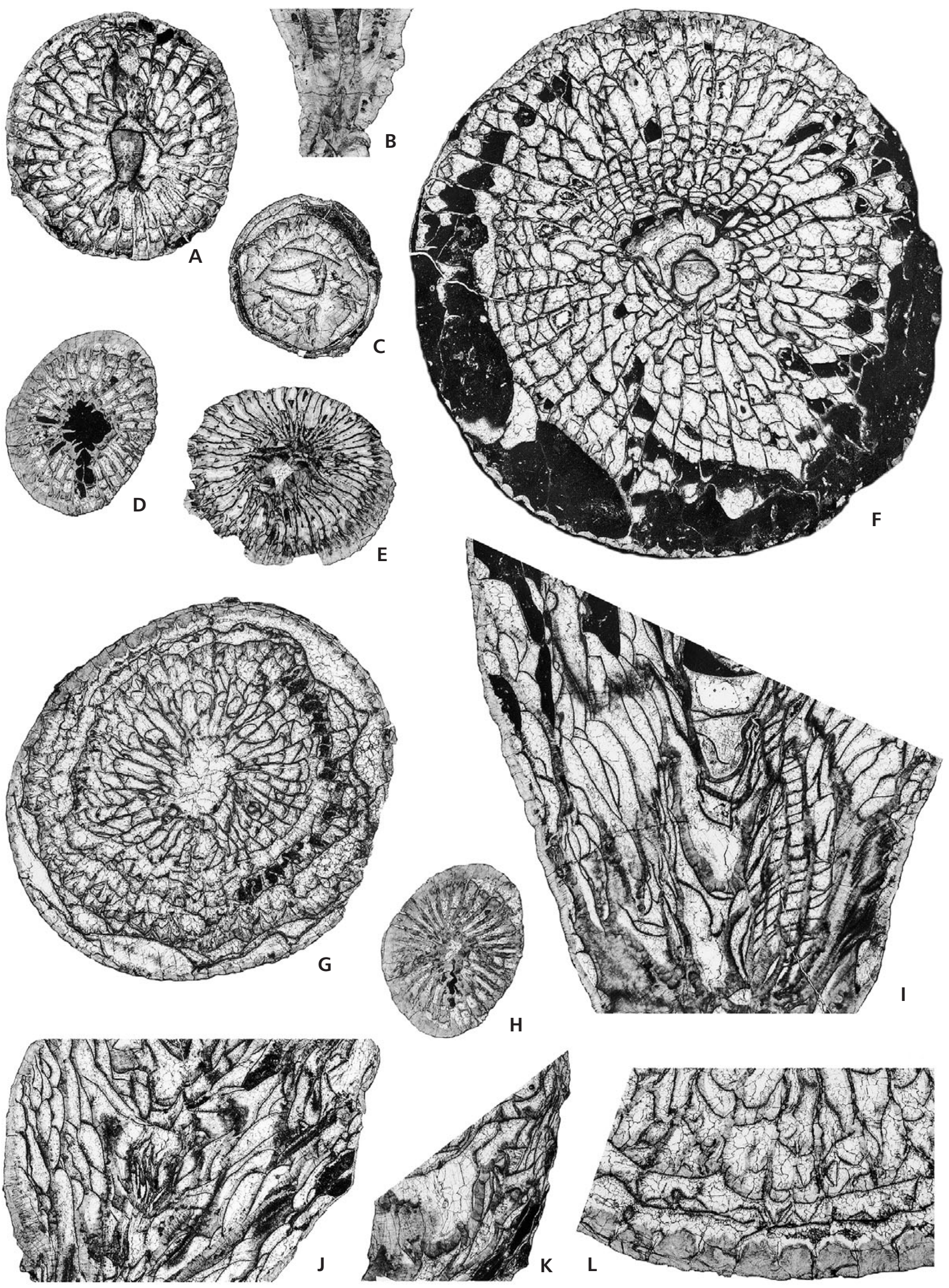
both boss and platform. Maximum diameter and length estimated $>41 \mathrm{~mm}$ and $80 \mathrm{~mm}$. Evidence of rejuvenescense confined to a few specimens with a flattened tabula overlying a preceeding calice, and in one specimen, overlain by thickened rejuvenated septa (Fig. 7R). Periphery septothecate, mostly thin in late stages, although prominent septal bases locally may produce a more robust wall (Fig. 6L).

Brephic stages not preserved. In an early neanic stage (dc $5 \mathrm{~mm}$, Fig. $7 \mathrm{~N}$ ) there are about 22 mostly contiguous septa, and the septal arrangement is bilateral about a relatively large cardinal septum and discernible counter septum. A transverse section of a slightly later neanic stage (dc $6.5 \mathrm{~mm}$, Fig. 7K) shows a similar number of septa and some narrow interseptal loculi. A specimen with elliptical transverse outline (average dc about $12.5 \mathrm{~mm}$, Fig. 6D, H) has shortened cardinal and counter septa, 29 other major septa, a few short minor septa and pronounced cardinal bilateral symmetry. Another late neanic section (dc $13 \mathrm{~mm}$, Fig. 7G) of a damaged specimen shows heavy sclerenchymal coating of the adaxial parts of the major septa and continued strong cardinal bilateral symmetry. There are 30 major septa in addition to the cardinal septum and almost as many minor septa. The lower transverse section of the holotype (dc $16 \mathrm{~mm}$, Fig. 6E) is partly decorticated. There are estimated to be 36 major septa, much coated with sclerenchyme, which almost totally engulfs the minor septa. None of the septa is withdrawn from the periphery; symmetry in this late neanic stage remains essentially bilateral. The neanic stage may continue to dc $21 \mathrm{~mm}$. In an example of this (Fig. $7 \mathrm{~J}$ ), there are $37 \times 2$ septa, with short minor septa visible in most interseptal loculi.

Peripheral septal withdrawl, reduction of sclerenchyme and near radial septal symmetry with weak cardinal fossula characterise ephebic stages. The smallest example in the type series having any of these features (dc $19 \mathrm{~mm}$, Fig. 7A) has three major septa based on one presepiment and a single major septum based on an adjacent presepiment. In late ephebic stages, most septa are withdrawn from the septotheca. Septa exhibit small-scale bends in transverse section, but are not carinate, and there is a narrow periaxial region free of septa. Septal counts are $35 \times 2$ (dc 29, Fig. 6G), $38 \times 2$ (dc 28 mm, Fig. 7A), $41 \times 2$ (dc $35 \mathrm{~mm}$, Fig. 7E), and in holotype, $43 \times 2$ (dc $41 \mathrm{~mm}$, Fig. $6 \mathrm{~F})$.

Dissepiments elongate, typically in no more than two rows in brephic stages. In ephebic stages, marginarium comprises large presepiments and dissepiments in as many as eight rows. Dissepimentarium and tabularium not clearly distinguished in brephic stages. In neanic stages, tabularium distinguished as the cylindrical periaxial space not penetrated by major septa. Tabulae periaxially depressed and irregularly spaced.

Etymology. - Patronym for G.B. Pauly who helped collect the type series.

Occurrence. - Presently known only from the type stratum and locality.

Remarks. - The small cylindrical corallite illustrated in Fig. 6C, which has a thin nonseptate wall, large presepiments and short septa, does not fit the ontogenetically framed description given for the species. Except for its small size and cylindrical shape, the unillustrated longitudinal section is typical of the species. The corallite (USNM 539827) is tentatively interpreted as a failed intracalicular bud of Romanophyllum paulyi, and not evidence of a second species in the genus.

Family Ptenophyllidae Wedekind, 1923

Remarks. - Originally proposed (Wedekind, 1923, p. 33) as a subfamily of the Cyathophyllidae. Promoted to family rank by Wedekind (1924, p. 35).

\section{Genus Xystriphyllum Hill, 1939}

?1938 Kozlowiaphyllum n.; Rukhin, p. 34.

non 1938 Entelophyllum (Entelophylloides) subgen. n.; Rukhin, p. 23.

1939 Xystriphyllum n.; Hill, p. 62 in part (includes Entelophylloides).

1966 Xystriphyllum Hill, 1939. - Strusz, p. 577.

1970 Xystriphyllum Hill, 1939. - Jell \& Hill, p. 100.

1970 Xystriphyllum Hill. - Oliver \& Galle, p. 57.

1981 Xystriphyllum Hill, 1939. - Hill, p. F244.

?1990 Hinganophyllum n.; Guo, pp. 30, 35.

1995 Xystriphyllum Hill, 1939. - Lin et al., p. 281.

Type species. - Cyathophyllum dunstani Etheridge, 1911, p. 3, pl. A, figs 1, 2. Lower Palaeozoic limestone; Clermont, Queensland. The type stratum is in the Douglas Creek Limestone of current terminology. From conodonts in the limestone (Philip \& Pedder, 1968, p. 1037 - their $P$. linguiformis foveolata is Polygnathus perbonus) and brachiopods in the overlying siltstone (Brock \& Talent 1993), the type occurrence is Emsian, gronbergi/perbonus to inversus Zone age. The exact type locality is not known, but

Figure 7. Romanophyllum paulyi gen. et sp. nov. Topotypic paratypes from Sadler Ranch Formation, all × 2 . A, F - USNM 539817 from $1990-31$. • B, L - USNM 539820 from 1990-31. • C, D - USNM 539819 from 1990-31. • E, H, O - USNM 539823 from 1996-5. • G, M - USNM 539824. • I, N - USNM 539821 from 1990-31. • J, K, P - USNM 539818 from 1990-31. • Q, R - USNM 539822 from1990-31/13. 
Alan E.H. Pedder • Lower-Middle Devonian rugose coral faunas of Nevada
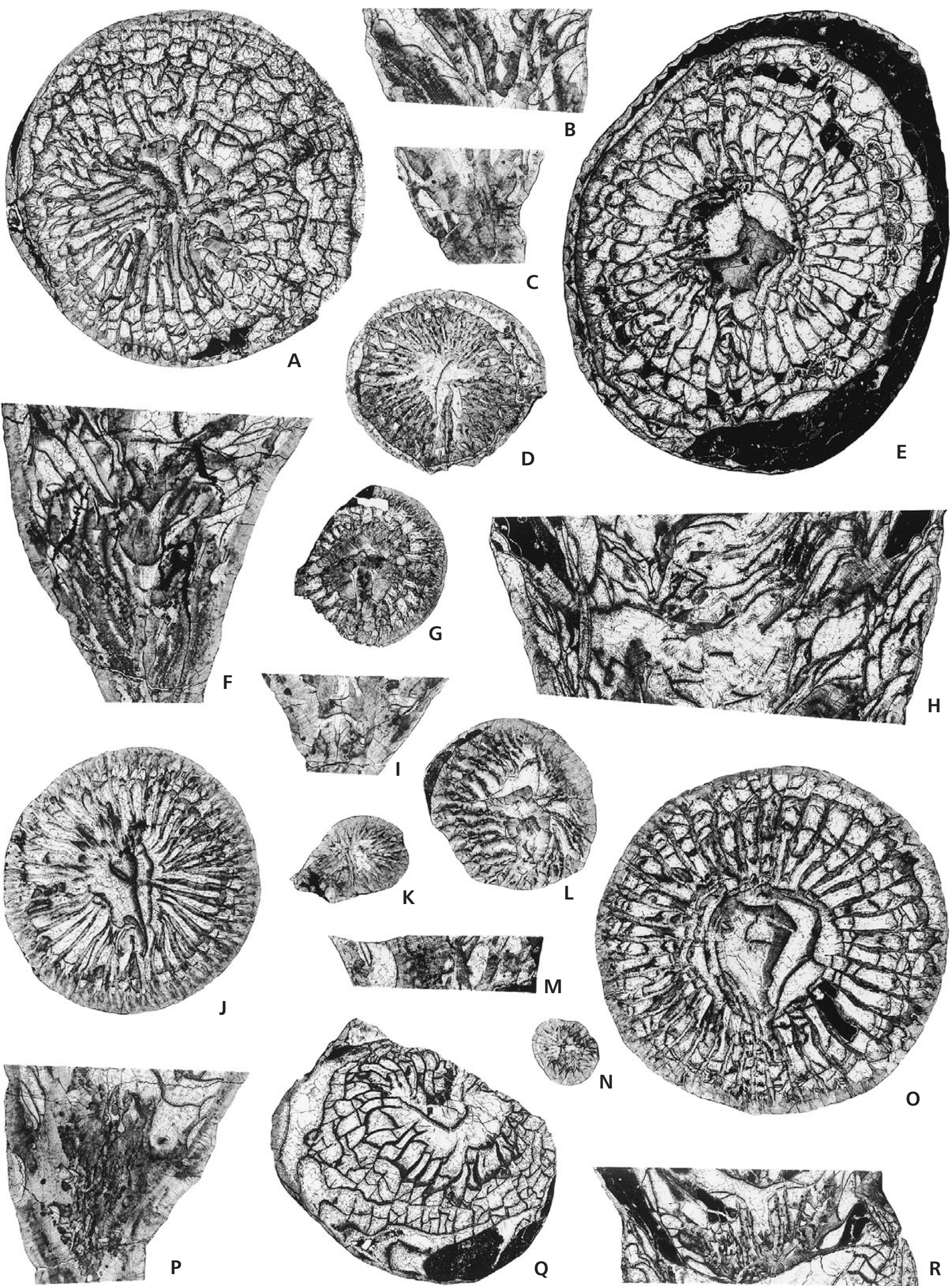
is one of several isolated exposures of the Douglas Creek Limestone around Douglas Creek Homestead, 8-10 km south-southwest of Clermont. A full description of the type species, including choice of lectotype, was given by Hill (1939, p. 63). The lectotype has been illustrated by Hill (1939, pl. 5, fig. 6a, b; 1981, fig. 1541, e) and by Jell \& Hill (1970, pl. 4, fig. 1a, b), and Strusz (1966, pl. 91, fig. 2a, b) has provided good illustrations of a paralectotype. Jell \& Hill's (1970, p. 101) remarks concerning the type species are especially useful for discriminating Xystriphyllum from Australophyllum Stumm, 1949.

Type species of Kozlowiaphyllum. - K. pentagonum Rukhin, 1938, p. 34, 99, pl. 3, figs 9, 10. "Upper part of the Upper Silurian"; right bank of Yasachnaya River below mouth of River Torynakh, upper Kolyma River basin, northeastern Russia. The level of the type stratum given by Rukhin is probably wrong. It is more likely to be in the Lochkovian-Eifelian succession, which, on Yasachnaya River, rests unconformably on Ordovician-lower Silurian beds, and includes fossiliferous Eifelian limestone (Gagiev 1997, column 8, fig. 3, p. 80). The type material is lost (Ivanovskiy 1976, p. 94).

Type species of Hinganophyllum. - H. polygonalis Guo, 1990, p. 30, 36, pl. 3, fig. 1a, b, pl. 4, fig. 1. Wunur Formation; Weinahe River, Toudaoquiao district, about $150 \mathrm{~km}$ south of Hailar City, Ewenkizu Autonomous County, Inner Mongolia, China. Guo believed the type horizon to be early Middle Devonian, but the coral fauna of the Wunur Formation is more consistent with the Emsian age given to the formation by Wang Cheng-yuan (2001, p. 446).

Remarks. - There is little doubt that the type species of Rukhin's available genus Kozlowiaphyllum, which is not a nomen oblitum, is congeneric with Xystriphyllum trojani sp. nov. Rukhin's and Soshkina's (in Soshkina et al. 1962, p. 335) descriptions of Kozlowiaphyllum pentagonum suggest it has a typical ptenophyllid tabularium. However, illustration of a longitudinal section and other knowledge of $K$. pentagonum are desirable before Kozlowiaphyllum is substituted for Xystriphyllum.

\section{Xystriphyllum trojani sp. nov.}

Figures 3A, B, 9A-E

Type series. - Holotype, USNM 539832 from 1996-34. One approximately topotypic paratype, USNM 539833 from 1996-36. Type occurrence is in a debris flow, 4.6-4.9 m above base of the Denay Limestone, lower Eifelian, costatus Zone; TA Va section, northern Antelope Range.

Diagnosis. - Species of Xystriphyllum with mean adult dc 13-19 mm, and narrow subcylindrical tabularia with adult diameters $2.5-4.4 \mathrm{~mm}$. Septa thin and mostly complete, numbering $16 \times 2-26 \times 2$ per adult corallite. Dissepiments small, abundant, in as many as 16 rows.

Description. - Corallum cerioid, large with many commonly five-sided prismatic corallites. Mean adult dc 13-18 $\mathrm{mm}$ in holotype, $15-19 \mathrm{~mm}$ in the slightly better preserved paratype. Increase marginarial, nonparricidal. Offsets generated one at a time, normally in a corner of the parent corallite.

Septothecae from adjacent corallites combine to form wall between corallites. Septal bases prominent, wedgeshaped and trabeculate. Contiguous septal bases forming an intercorallite wall may be back-to-back, or offset causing the wall to be somewhat sinuous. Thinnest parts of intercorallite wall, where septal bases are back-to-back, 0.15-0.5 mm thick. In dissepimentarium, septa undifferentiated, finely trabeculate, thin, slightly crenulate but noncarinate, and radially arranged. Most septa are continuous. A few are briefly ruptured close to their base, especially in corners of large irregular prismatic corallites, where offsets are likely to develop. Minor septa terminate just inside the tabularium; major septa extend to the periaxial area where they are very slightly thickened, weakly flanged, and variably twisted. The fine trabecuale are long, parallel, straight and inwardly inclined $40-45^{\circ}$ to horizontal in the marginarium. Septal counts in immature corallites (dc 6-9.5 mm) $16 \times 2-21 \times 2$, and in mature corallites (dc 14-19 mm) $23 \times 2-26 \times 2$.

Dissepiments small, abundant, moderately inflated and inwardly inclined at $40-45^{\circ}$ to horizontal throughout most of the dissepimentarium. Inclination of innermost dissepiments increases adaxially, so that transition from dissepimentarium to tabularium is abrupt in the normal ptenophyllid manner. Eight to sixteen rows of dissepiments present in typical adult corallites. Tabularium subcylindrical, narrow relative to corallite width, with adult diameters $2.5-3.5 \mathrm{~mm}$ in holotype, and as much as $4.4 \mathrm{~mm}$ in some paratype corallites. Tabularial surfaces variably depressed. Tabulae incomplete, closely spaced, 30-40 occur over a vertical distance of $10 \mathrm{~mm}$.

Etymology. - Patronym for W.R. Trojan, in recognition of his important work in the northern Antelope Range.

Figure 8. Breviphrentid gen. undetermined, Bartine Member, Lone Mountain (A, E, G) and northern Roberts Mountains (B-D, I), and Romanophyllum? sp. Bartine Member, Lone Mountain (F, H, J)・•A, E, G - USNM 539831 from 1997-51, × 2. • B-D - USNM 510051 from 1997-7, × 2. - I - USNM 510051 from 1997-7, part of transverse section, × 7. • F, H, J - USNM 539830 from 1990-18, × 1.9. 

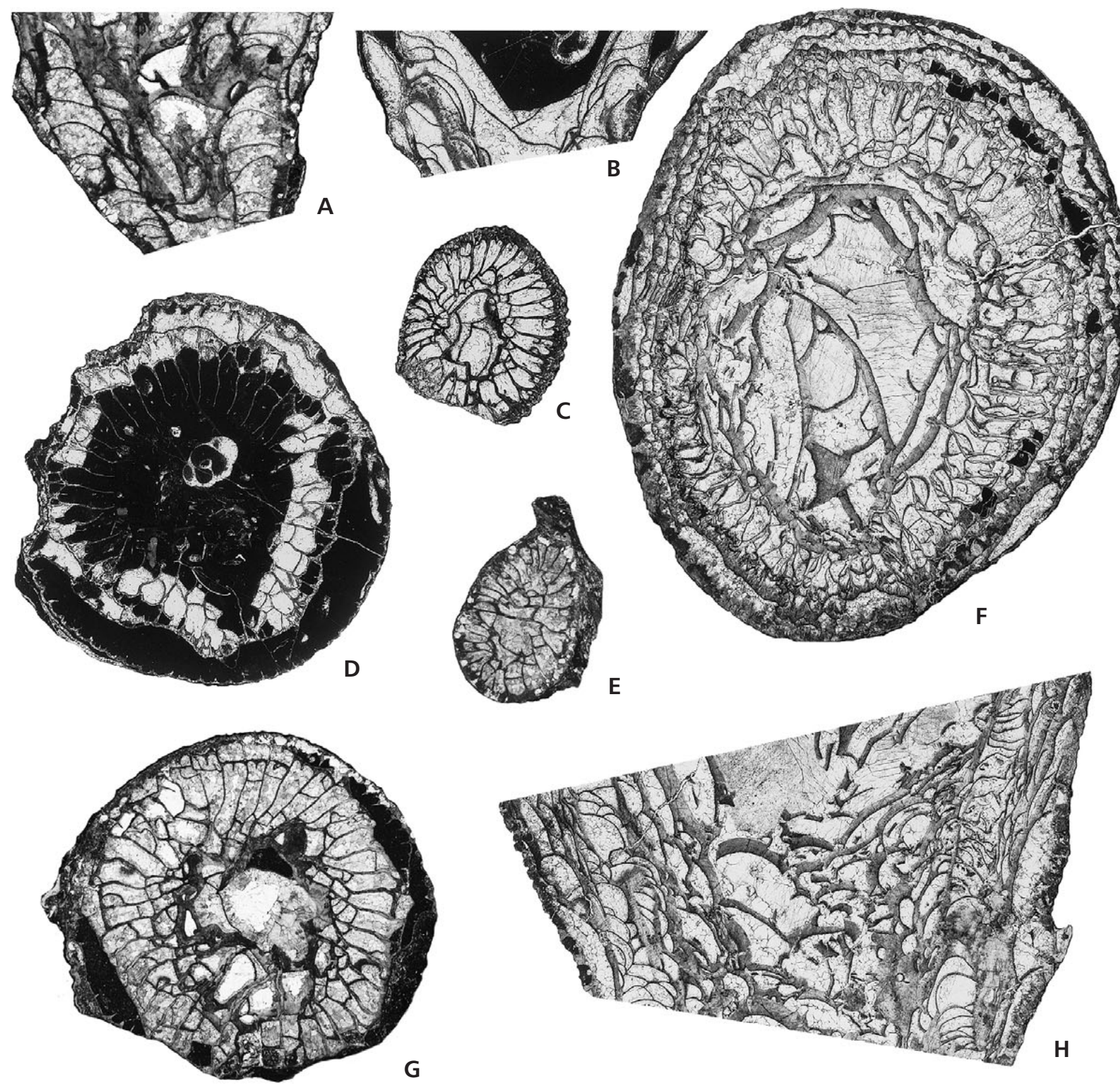

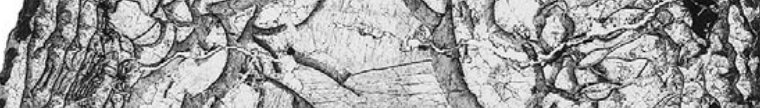

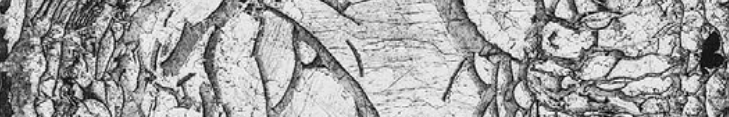
1. (12)
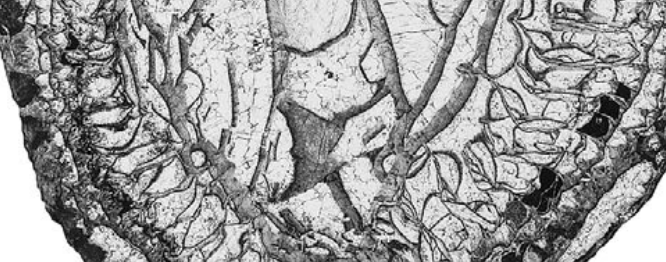

a. 1.2 .

2.

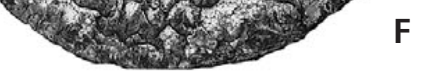

E
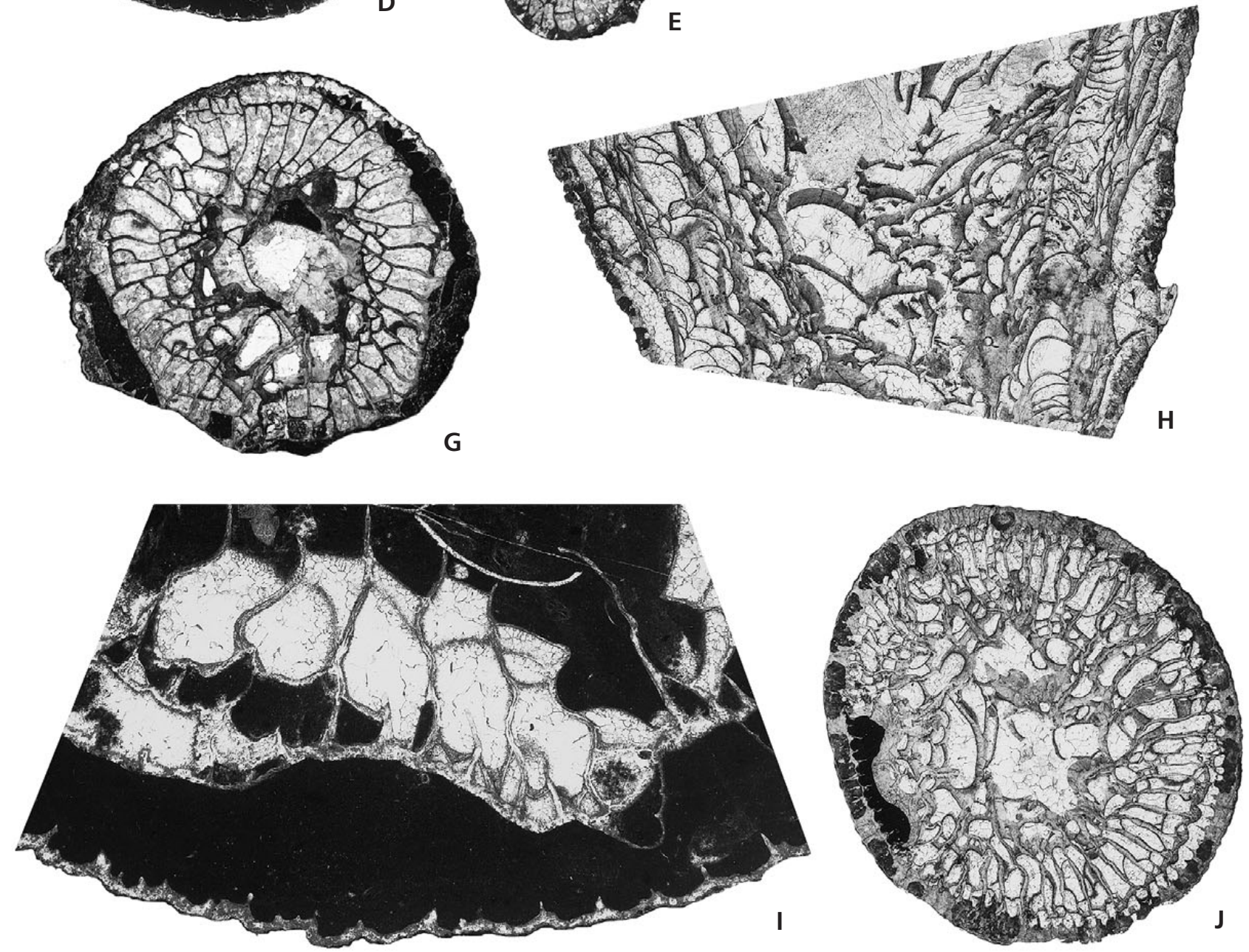

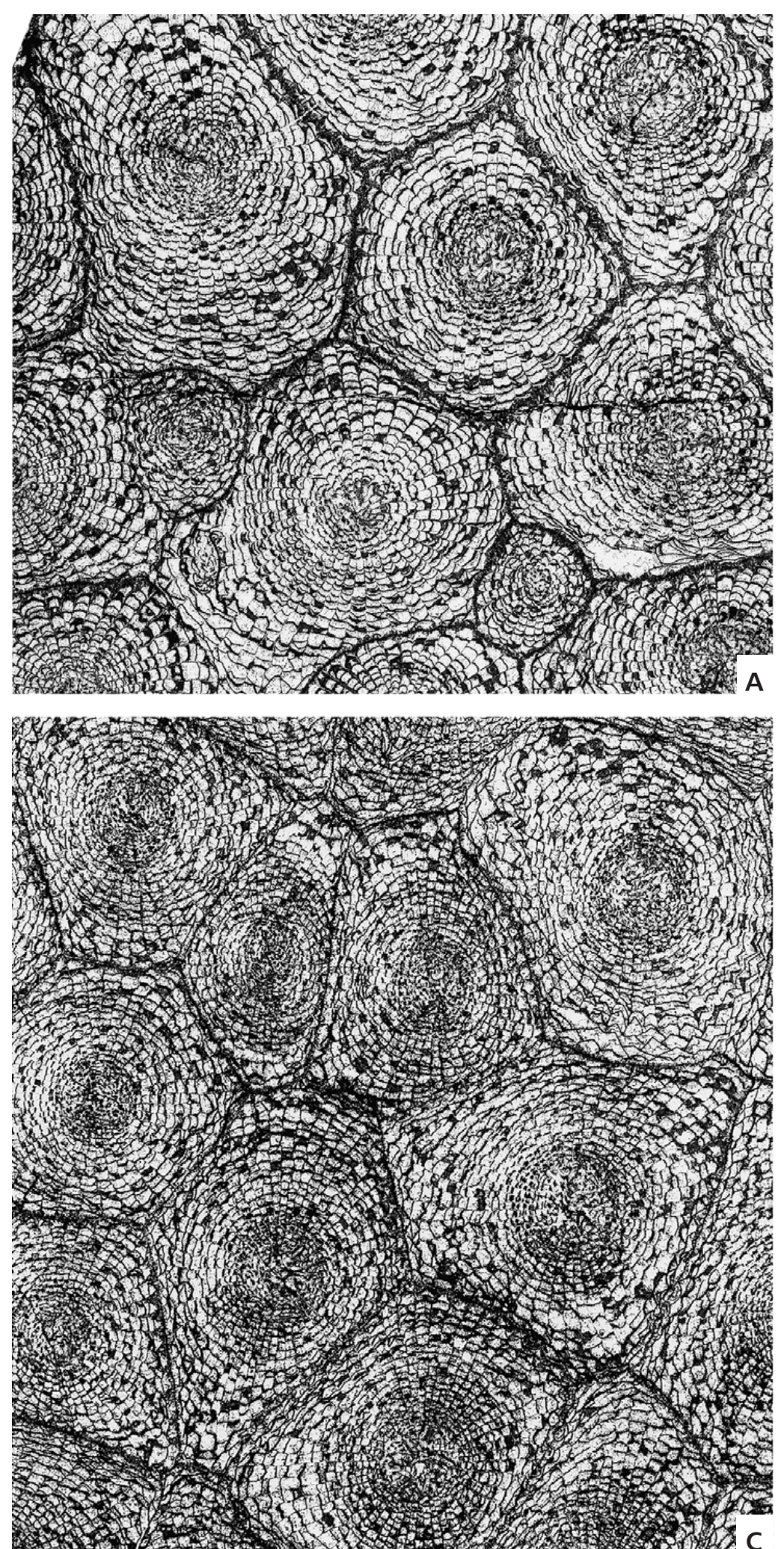
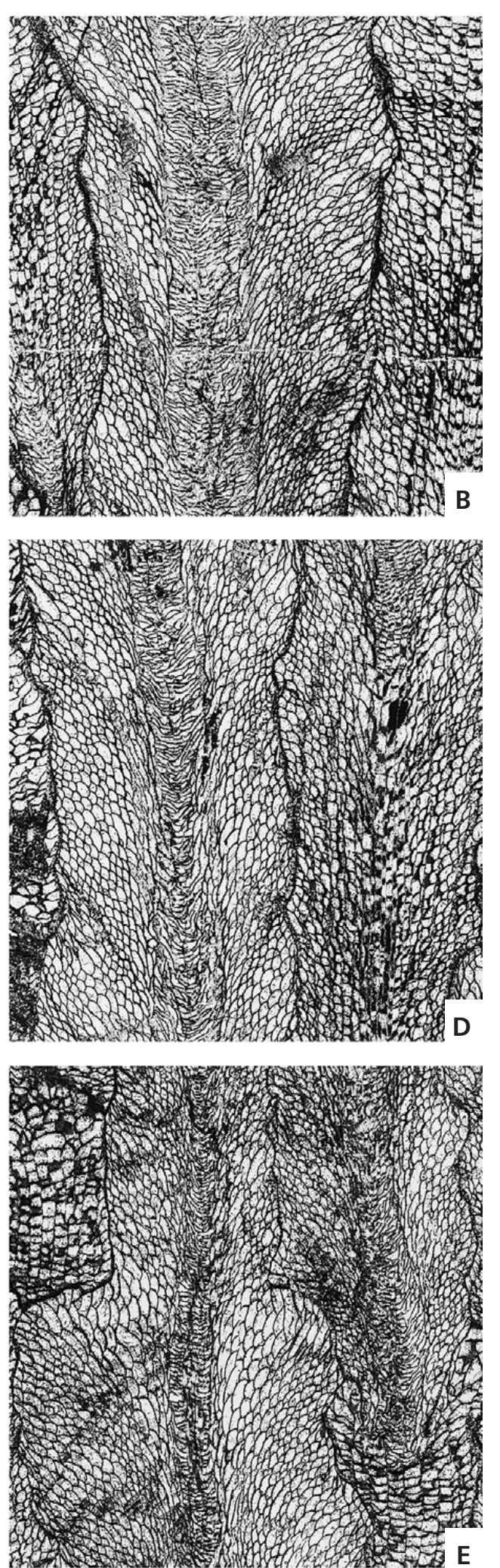

Figure 9. Xystriphyllum trojani sp. nov., debris flow near base of Denay Limestone, × 2.5. • A, B - paratype, USNM 539833 from $1996-36$. - C-E - holotype, USNM 539332 from 1996-34. 
Occurrence. - Known only as reworked specimens in the Sadler Ranch and basal Denay limestones of northern Antelope Range. Both lower Eifelian costatus Zone, but see biostratigraphy section.

Discussion. - The new species belongs to a group of large cerioid ptenophyllid corals, comprising species originally named Kozlowiaphyllum pentagonum Rukhin, 1938, Xystriphyllum magnum Hill, 1942 (p. 147, pl. 3, fig. 2a, b), Stenophyllum uralicum Soshkina, 1949 (p. 129, pl. 52, fig. 1a, b, pl. 53, fig. 5a, b), Australophyllum indigense Cherepnina, 1986 (in Ivaniya \& Cherepnina, p. 86, pl. 9, fig. 21b, pl. 10, fig. 21a) and Hinganophyllum polygonalis Guo, 1990. The group also includes an unnamed lower Eifelian species from Devon Island, Arctic Canada. These species differ from smaller, more typical species of Xystriphyllum by having a wide dissepimentarium with many relatively small dissepiments and a relatively narrow tabularium. Their septa are thin and locally discontinuous near the periphery. Hinganophyllum polygonalis and Xystriphyllum trojani differ from the other corals of the group in having prominent septal bases in a septothecate wall. Xystriphyllum trojani differs from Hinganophyllum polygonalis by its small size (dc in Guo's species as high as $35 \mathrm{~mm}$ ) and by its adaxial septal ends, which are only slightly inflated and not as strongly flanged and rhopaloid as those of Hinganophyllum polygonalis are.

\section{Conclusions}

The Devonian coral based E zone has been considered impoverished, even barren of corals and brachiopods for three reasons: 1) knowledge of Devonian corals in Nevada has largely been based on successions in the Roberts Mountains and Lone Mountain where an inferred disconformity appears to exclude much of the zone; 2) dolomitisation has severely affected the biota of the upper part of the zone in the "reference section" on Lone Mountain; 3) correlations made before the advent of a conodont based zonation were faulty in several instances - three coral species that should have been assigned to the $\mathrm{E}$ zone were assigned to the $\mathrm{D}$ zone.

Sections in southern Sulphur Spring and northern Antelope ranges reveal a hitherto unrecognised succession of rugose coral faunas: 1) Breviphrentis magna-Stummelasma antelopense assemblage, serotinus Zone and lower FI 14; 2) Synaptophyllum romanense-Romanophyllum paulyi assemblage, patulus Zone and middle FI 14; 3) assemblage of mostly undescribed species including the earliest post Lochkovian ptenophyllids in Nevada, partitus Subzone and upper FI 14; 4) assemblage including Mesophyllum kirki sense of Merriam (1974), Sociophyllum sp. and possibly (may be lower australis Zone) Exilifrons strict sense and Utaratuia, upper costatus Zone and FI 15.
The turnover from the second to third of these assemblages in partitus to lower costatus Zone time is profound. It marks the end of the Pragian-Emsian Great Basin coral province and appears to correspond to the Choteč Event of the Bohemian massif.

Identifications of Synaptophyllum and discoveries of ptenophyllid genera Dohmophyllum, Taimyrophyllum and Xystriphyllum in patulus and lower costatus zones are important in defining the three-step change from Lower to Middle Devonian coral faunas in the Great Basin.

\section{Acknowledgements}

M.A. Murphy, Riverside, introduced the writer to the Devonian of Nevada and made his wide knowledge of it available on many occasions. He also identified most of the conodonts reported from the ROM I-IV sections. Answers to questions put to R. Feist, Montpellier, S. Rodríguez, Madrid, F. Soto, Oviedo, and to J. Craig, Bragg Creek, have been most helpful. T.T. Uyeno, Calgary, identified conodonts in a sample from the ROM III section. Figures 1-9 were prepared by G. Edwards (digital imaging), B.C. Rutley (photography) and D.R. Then (vector graphics), all GSC Calgary. E.T.W. Hau and J. McCloskey, also GSC Calgary, provided excellent library assistance. Careful reviews of the original paper by A. Galle, Praha, and R.A. McLean, Calgary, were most helpful and sincerely appreciated. Although the author acknowledges and is deeply grateful for this help, responsibility for errors remain entirely with the author.

\section{References}

ALtevoGt, G. 1968. Devonian tetracorals from Spain and their relation to North American species, 755-769. In OSWALD, D.H. (ed.) International Symposium on the Devonian System, Calgary, 1967, Volume 2. Alberta Society of Petroleum Geologists, Calgary.

ARbizU, M., GARCÍA-AlCALDE, J.L., GarCíA-LÓPEZ, S., MÉndeZ-Bedia, I., SÁnChez de PosadA, L.C., Soto, F.M., Truyóls, M., Truyóls, J., Alvarez, F., MÉndez, C. \& MENÉNDEZ, J.R. 1979. Biostratigraphical study of the Moniello Formation (Cantabrian Mountains, Asturias, NW Spain). Geologica et palaeontologica 13, 103-124.

AZor, A., RubatTo, D., SimANCAS, J.F., GONZÁlez Lodeiro, F., MARTÍNEZ POYATOS, D., MARTÍN PARRA, L.M. \& MATAS, J. 2008. Rheic Ocean ophiolitic remnants in southern Iberia questioned by SHRIMP U-Pb zircon ages on the BejaAcebuches amphibolites. Tectonics 27, TC5006. DO] 10.1029/2008TC002306

BABCOCK, L.E. 1996. Phyllum Cnidaria, 70-89. In FELdMANN, R.M. (ed.) Fossils of Ohio. Ohio Department of Natural Resources, Division of Geological Survey, Bulletin 70.

BELANSKI, C.H. 1928. Descriptions of some typical fossils of the Shellrock stage. The American Midland Naturalist 11(5), 171-212.

BEST, E.W. 1953. Pre-Hamilton Devonian stratigraphy, southwestern Ontario, Canada. 238 pp. Ph.D. thesis, University of Wisconsin, Madison. 
BILlingS, E. 1858. Report for the year 1857 of E. Billings, Esq., Palaeontologist, addressed to Sir W.E. Logan, F.R.S., Director of the Geological Survey of Canada. Geological Survey of Canada, Report of Progress for the Year 1857, 147-192.

BILLINGS, E. 1859. On the fossil corals of the Devonian rocks of Canada West. The Canadian Journal of Industry, Science, and Art, new series 4, 97-140.

BILLINGS, E. 1875? On some new or little known fossils from the Silurian and Devonian rocks of Ontario. Canadian Naturalist and Quarterly Journal of Science, new series 7(4), 230-240. [date of imprint 1874]

BIRENHEIDE, R. 1962. Revision der koloniebildenden Spongophyllidae und Stringophyllidae aus dem Devon. Senckenbergiana lethaea 43(1), 41-99.

BOLTON, T.E. 1966. Illustrations of Canadian fossils; Silurian faunas of Ontario. Geological Survey of Canada Paper 66-5, 1-46.

BROCK, G.A. \& TALENT, J.A. 1993. Emsian (Early Devonian) brachiopods from the Ukalunda Beds and Douglas Creek, north Queensland, 225-248. In JELL, P. (ed.) Palaeontological studies in honour of Ken Campbell. Association of Australiasian Palaeontologists Memoir 15.

CAO XUAN-DUO 1987. Biostratigraphy, 1. Tetracorals, 50-56. In XI'AN INSTITUTE OF GEOLOGY AND MINERAL RESOURCES \& NANJING Institute OF GEOLOGY AND PALAEONTOLOGY (eds) Late Silurian-Devonian strata and fossils from Luqu-Tewo area of West Qinling Mountains, China, volume 1. Nanjing University Press, Nanjing. [in Chinese]

CAO XUAN-DuO \& OUYANG XuAN 1987. Palaeontological descriptions, 1. Late Silurian and Devonian rugose corals from Luqu and Tewo regions, West Qinling Mountains, 139-202. In XI'AN INSTITUTE OF GEOLOGY AND MINERAL RESOURCES \& NANJING InSTITUTE OF GEOLOGY AND PALAEONTOLOGY (eds) Late Silurian-Devonian strata and fossils from LuquTewo area of West Qinling Mountains, China, volume 1. Nanjing University Press, Nanjing. [in Chinese with English abstract]

CAO XUAn-DuO, OuYAng XuAN \& Jin TONG-An 1983. Rugosa, 46-179, 565-593. In XI'AN INSTITUTE OF GEOLOGY AND Mineral ReSOURCES (ed.) Paleontological atlas of Northwest China, Shaanxi, Gansu and Ningxia Volume, 2, Upper Palaeozoic. Geological Publishing House, Beijing. [in Chinese; date of imprint 1982]

CASTElnaU, F. DE. 1843. Essai sur le système silurien de l'Amérique Septentrionale. 56 pp. P. Bertrand, Paris.

CHLUPÁČ, I. \& KUKAL, Z. 1986. Reflection of possible global Devonian events in the Barrandian area, C.S.S.R., 169-179. In WALLISER, O.H. (ed.) Global Bio-Events. Lecture Notes in Earth Sciences 8. Springer-Verlag, Berlin, Heidelberg.

CRICKMAY, C.H. 1957. Elucidation of some western Canada Devonian formations. 15 pp. C.H. Crickmay, Calgary.

DAVIES, W.J. 1887. Kentucky fossil corals. A monograph of the fossil corals of the Silurian and Devonian rocks of Kentucky. Part 2 (Part 1 never published). xiii pp., 139 pls. Kentucky Geological Survey, Frankfort. [date of imprint 1885]

DE FROMENTEL, E. 1861. Introduction à l'étude des polypiers fossiles. 357 pp. F. Savy, Paris.

EASTON, W.H. 1957. On the tetracoral Lithostrotion harmodites Milne-Edwards and Haime. Journal of Paleontology 31(3), 616-622.

ETHERIDGE, R., JR. 1911. The Lower Palaeozoic corals of Chilla- goe and Clermont. Part 1. Geological Survey of Queensland Publication 231, 8 pp.

FAgerstrom, J.A. 1961. The fauna of the Middle Devonian Formosa reef limestone of southwestern Ontario. Journal of Paleontology 35(1), 1-48.

FENTON, C.L. \& FENTON, M.A. 1924. The stratigraphy and fauna of the Hackberry stage of the Upper Devonian. Contributions from the Museum of Geology, University of Michigan 1, xi + $1-260$.

FlüGEL, H.W. \& Hubmann, B. 1994. Catalogus fossilium austriae. Ein systematisches Verzeichnis aller auf österreichischem Gebiet festgestellten Fossilien. IV c/la. Anthozoa palaeozoica: Rugosa. $141 \mathrm{pp}$. Verlag der Österreichischen Akademie der Wissenschaften, Wien.

FRANKE, W. 1999. Tectonic and plate tectonic units at the north Gondwana margin: Evidence from the central European Variscides, 7-13. In FEIST, R., TALENT, J.A. \& DAURER, A. (eds) North Gondwana: mid-Paleozoic terranes, stratigraphy and biota. Abhandlungen der Geologischen Bundesanstalt 54.

GAGIEV, M.H. 1997. Sedimentary evolution and sea-level fluctuations in the Devonian of North-East Asia. Courier Forschungsinstitut Senckenberg 199, 75-82.

GARCÍA-LÓPEZ, S. \& SANZ-LÓPEZ, J., with contribution by SARMIENTO, G.N. 2002. The Palaeozoic succession and conodont biostratigrpahy of the section between Cape Peñas and Cape Torres (Cantabrian coast, NW Spain), 125-156. In GARCÍA-LÓPEZ, S. \& BASTIDA, F. (eds) Palaeozoic conodonts from northern Spain. Cuadernos del Museo Geominero, 1.

GLINSKI, A. 1957. Taxionomie und Stratigraphie einiger Stauriidae (Pterocorallia) aus dem Devon des Rheinlandes. Senckenbergiana lethaea 38(1/2), 83-108.

GOLONKA, J. 2002. Plate-tectonic maps of the Phanerozoic, 21-75. In Kiessling, W., FlÜGEl, E. \& GolonkA, J. (eds) Phanerozoic reef patterns. Society for Sedimentary Geology Special Publication 72.

Greenman, C., Chatterton, B.D.E., Boucot, A.J. \& BerRy, W.B.N. 1977. Coarse Silurian(?) and Devonian detrital rocks in northeastern Washington: Evidence of Silurian(?) and Devonian tectonic activity, 467-479. In STEWART, J.H., STEVENS, C.H. \& FRITSCHE, A.E. (eds) Paleozoic paleogeography of the western United States. Society of Economic Paleontologists and Mineralogists, Pacific Section, Los Angeles.

GUO SHENGZHE 1990. Early and Middle Devonian rugose corals from Toudaoqiao district of central Da Hinggan Ling (Mts.). Bulletin of the Shenyang Institute of Geology and Mineral Resources, Chinese Academy of Geological Sciences 18, 25-36. [in Chinese with English abstract; date of imprint 1989]

HALL, J. 1852. Palaeontology of New York, volume 2, Natural History of New York, part 6. viii +363 pp. Authority of the State of New York, C. van Benthuysen, Albany.

HILL, D. 1939. The Middle Devonian rugose corals of Queensland, I. Douglas Creek and Drummond Creek, Clermont district. Proceedings of the Royal Society of Queensland 50(10), 55-65.

HILL, D. 1942. The Devonian rugose corals of the Tamworth district, N.S.W. Journal and Proceedings of the Royal Society of New South Wales 76(3), 242-264.

HiLl, D. 1956. Coelenterata, Part F, Rugosa, F233-F324. In MOORE, R.C. (ed.) Treatise on Invertebrate Paleontology. Geological Society of America \& University of Kansas Press, Lawrence. 
HiLl, D. 1981. Coelenterata, Part F, Supplement 1, Rugosa and Tabulata, F1-F378 (v. 1), F379-F762 (v. 2). In TEICHERT, C. (ed.) Treatise on Invertebrate Paleontology. Geological Society of America \& University of Kansas Press, Lawrence.

Hou Hong-FeI \& BouCOT, A.J. 1990. The Balkhash-Mongolia-Okhotsk region of the Old World Realm (Devonian), 297-303. In MCKerRow, W.S. \& SCOTESE, C.R. (eds) Palaeozoic palaeogeography and biogeography. The Geological Society of London Memoir 12.

IVANIYA, V.A. \& CHEREPNINA, S.K. 1986. Devonskie korallyrugozy Zapadnoy Sibiri. 136 pp. Izdatel'stvo Tomskogo Universiteta, Tomsk.

IVANOVSKIY, A.B. 1965. Stratigraficheskiy i paleobiogeograficheskiy obzor rugoz ordovika i silura. 120 pp. Izdatel'stvo Nauka, Moskva.

IVANOVSKIY, A.B. 1976. Ukazatel' rodov rugoz. Akademiya Nauk SSSR, Sibirskoe Otdelenie, Trudy Instituta Geologii i Geofiziki $217,256 \mathrm{pp}$.

IVANOVSKIY, A.B. 1978. Izmenchivost' i sistema siluriyskikh rugoz roda Entelophyllum, 95-103, 127, 128. In TESAKOV, Y.I. \& KulKov, N.P. (eds) Fauna i biostratigrafiya verkhnego ordovika i silura Altae-Sayanoy oblasti. Izdatel'stvo Nauka, Moskva.

JELL, J.S. \& HILL, D. 1970. Revision of the coral fauna from the Devonian Douglas Creek Limestone, Clermont, central Queensland. Proceedings of the Royal Society of Queensland 81(10), 93-120.

JOHNSON, J.G. 1962. Lower Devonian-Middle Devonian boundary in central Nevada. Bulletin of the American Association of Petroleum Geologists 46(4), 542-546.

JoHNSON, J.G. 1966. Middle Devonian brachiopods from the Roberts Mountains, central Nevada. Palaeontology 9(1), 152-181.

JOHNSON, J.G. 1977. Lower and Middle Devonian faunal intervals in central Nevada based on brachiopods, 16-32. In MURPHY, M.A., BERRY, W.B.N. \& SANDBERG, C.A. (eds) Western North America: Devonian. University of California, Riverside Campus Museum Contribution 4.

JoHnSON, J.G. 1990. Lower and Middle Devonian brachiopoddominated communities of Nevada, and their position in a biofacies-province-realm model, with a section on revision of Middle Devonian conodont zones by G. Klapper and J.G. Johnson. Journal of Paleontology 64(6), 902-941.

JOHNSON, J.G., BOUCOT, A.J. \& GRONBERG, E.C. 1968. A new genus of stringocephaloid brachiopod from the Middle Devonian of Nevada. Journal of Paleontology 42(2), 406-414.

Johnson, J.G., HiLdRETH, G.D., KendALl, G.W. \& Trojan, W.R. 1981. Biostratigraphy and biotopes of the lower Middle Devonian Leptathyris circula Zone, central Nevada. Journal of Paleontology 55(4), 814-825.

Johnson, J.G., KlapPer, G. \& Elrick, M. 1996. Devonian transgressive-regressive cycles and biostratigraphy, northern Antelope Range, Nevada: Establishment of reference horizons for global cycles. Palaios 11(1), 3-14. DOI 10.2307/3515112

JOHNSON, J.G., KLAPPER, G., MURPHY, M.A. \& TROJAN, W.R. 1986. Devonian series boundaries in central Nevada and neighboring regions, western North America. Courier Forschungsinstitut Senckenberg 75, 177-196. [date of imprint 1985]

JOHNSON, J.G., KLAPPER, G. \& TROJAN, W.R. 1980. Brachiopod and conodont successions in the Devonian of the northern Ante- lope Range, central Nevada. Geologica et palaeontologica 14, $77-116$.

JOHNSON, J.G. \& OLIVER, W.A., JR. 1977. Silurian and Devonian coral zones in the Great Basin, Nevada and California. Geological Society of America Bulletin 88(10), 1462-1468.

DOI 10.1130/0016-7606(1977)88<1462:SADCZI >2.0.CO;2

KELLER, M. \& GRÖTSCH, J. 1990. Depositional history and conodont biostratigraphy of the Lower Devonian La Vid Group in the Luna area (Cantabrian Mountains, NW Spain). Neues Jahrbuch für Geologie und Paläontologie, Monatshefte, Jahhgang 1990(3), 141-164.

Kendall, G.W., Johnson, J.G., Brown, J.O. \& KlapPer, G. 1983. Stratigraphy and facies across Lower Devonian-Middle Devonian boundary, central Nevada. The American Association of Petroleum Geologists Bulletin 67(12), 2199-2207.

KIRCHGASSER, W.T., OLIVER, W.A., JR. \& RICKARD, L.V. 1985. Devonian series boundaries in the eastern United States. Courier Forschungsinstitut Senckenberg 75, 233-260.

KLAPPER, G. 1977. Lower and Middle Devonian conodont sequence in central Nevada, with contributions by D.B. Johnson, 33-54. In MURPHY, M.A., BERRY, W.B.N. \& SANDBERG, C.A. (eds) Western North America: Devonian. University of California, Riverside Campus Museum Contribution 4.

KLAPPER, G. \& JOHNSON, D.B. 1975. Sequence in conodont genus Polygnathus in Lower Devonian at Lone Mountain, Nevada. Geologica et palaeontologica 9(1), 65-83.

KLAPPER, G. \& OLIVER, W.A., JR. 1995. The Detroit River Group is Middle Devonian: Discussion on "Early Devonian age of the Detroit River Group, inferred from Arctic stromatoporoids". Canadian Journal of Earth Sciences 32(7), 1070-1073.

KLAPPER, G., ZIEGLER, W. \& MASHKOVA, T.V. 1978. Conodonts and correlation of Lower-Middle Devonian boundary beds in the Barrandian area of Czechoslovakia. Geologica et palaeontologica 12, 103-116.

KONG LEI \& HUANG YUN-Ming 1978. Tetracoralla, 35-161, 739-759. In GUIZHOU STRATIGRAPHY AND PALAEONTOLOGY WORK TEAM (ed.) Atlas of Palaeontology of the southwestern regions of China, Guizhou, I, Cambrian-Devonian. Geological Publishing House, Beijing. [in Chinese]

LAKHOV, G.V. 1982. O sistematicheskom polozhenii rugoz Disphyllum geinitzi i blizkikh vidov. Paleontologicheskiy Zhurnal 1982(3), 15-24.

LANG, W.D. 1938. Some further considerations on trends in corals. Proceedings of the Geological Association of London 49(2), 148-159. DOI 10.1016/S0016-7878(38)80014-6

LANG, W.D. \& SMITH, S. 1935. Cyathophyllum caespitosum Goldfuss, and other Devonian corals considered in a revision of that species. The Quarterly Journal of the Geological Society of London 91(4), 538-590.

LANG, W.D., Smith, S. \& Thomas, H.D. 1940. Index of Palaeozoic coral genera. 231 pp. British Museum (Natural History), London.

LAUB, R.S. 1983. The Silurian coral biostratigraphy of New York, 9-34. In SORAUF, J.E. \& OLIVER, W.A., JR. (eds) Silurian and Devonian corals and stromatoporoids of New York. International Association for the study of Fossil Cnidaria, Washington, D.C.

LiBERTY, B.A. \& BolTON, T.E. 1971. Paleozoic geology of the Bruce Peninsula area, Ontario. Geological Survey of Canada Memoir 360, 163 pp. 
Li JENSING 1987. Biostratigraphy, 9. Conodonts, 78-80. In XI'AN INSTITUTE OF GEOLOGY AND MINERAL RESOURCES \& NANJING InStitute OF GEOLOGY AND PALAEONTOLOGY (eds) Late Silurian-Devonian strata and fossils from Luqu-Tewo area of West Qinling Mountains, China, volume 1. Nanjing University Press, Nanjing. [in Chinese]

Li Minglu 1987. Early Devonian rugose corals from the Zhusilenghairhan area of western Nei Monggol and the Lower-Middle Devonian boundary, 67-79. In ZHU HONG, ZHENG ZHAOCHANG \& HE XINYI (eds) Palaeozoic biostratigraphy and tectonic evolution of the Alxa massif margin. Wuhan College of Geology Press, Wuhan. [Chinese with English abstract]

LIAO WEI-HUA 2002. Biotic recovery from the Late Devonian F-F mass extinction event in China. Science in China, series $D$ 45(4), 380-384.

LIAO WEI-HUA 2003. Devonian biostratigraphy of Dushan, southern Guizhou and its coral extinction events. Acta palaeontologica sinica 42(3), 417-427. [in Chinese with English summary]

LiAO WeI-HUA 2004. Coral recovery from the FrasnianFamennian mass extinction event in South China, 259-280, 1052. In RONG JIAYU \& FANG ZONGJIE (eds) Mass extinction and recovery - Evidences from the Palaeozoic and Triassic of South China. University of Science and Technology of China Press, Hefei. [in Chinese with English summary]

LiAO WEI-HUA \& LI DA-QING 1991. Species of rugose corals from Xihanshui Group of Qinling Mts. Acta palaeontologica sinica 30(5), 601-615. [in Chinese with English summary]

Lin BaOyu, Xu Shouyong, Jia Huizheng, Guo Shengzhe, OUYANG XUAN, WANG ZENGJI, DING YUNJIE, CAO XUANDUO, YAN YouYIN \& CHEN HUACHENG 1995. Monograph of Palaeozoic corals. Rugosa and Heterocorallia. vii + 778 pp.. Geological Publishing House, Beijing. [in Chinese with English abstract]

LODUCA, S.T. \& BRETT, C.E. 1991. Placement of the Wenlockian/Ludlovian boundary in western New York State. Lethaia 24, 255-264. DO] 10.1111/j.1502-3931.1991.tb01476.x

LONSDALE, W. 1845. Description of some Palaeozoic corals of Russia, 591-634. In MurCHISON, R.I., VERnEUIL, E. DE \& KEYSERLING, A. VON The Geology of Russia in Europe and the Ural Mountains. John Murray, London \& Bertrand, Paris.

MCLAREN, D.J. 1959. A revision of the Devonian coral genus Synaptophyllum Simpson. Geological Survey of Canada Bulletin 48, 15-33.

MCLEAN, R.A. 2005. Phillipsastreid corals from the Frasnian (Upper Devonian) of Western Canada: Taxonomy and biostratigraphic significance. 109 pp. NRC Research Press, Ottawa.

MCLEAN, R.A. 2007. Kyphophyllid rugose corals from the Frasnian (Upper Devonian) of Canada and their biostratigraphic significance. Palaeontographica canadiana 26, 1-109.

MCLEAN, R.A. \& PEDDER, A.E.H. 1987. Frasnian rugose corals of western Canada, part 2: The genus Smithiphyllum. Palaeontographica A 195, 131-173.

MERRIAM, C.W. 1940. Devonian stratigraphy and paleontology of the Roberts Mountains region, Nevada. Geological Society of America Special Papers 25, 1-114.

MERRIAM, C.W. 1974. Lower and Lower Middle Devonian rugose corals of the central Great Basin. United States Geological Survey Professional Paper 805, 1-83.
MiLne EdwaRdS, H. \& HAIME, J. 1850. A monograph of the British Fossil Corals. Introduction and chapter 1, Palaeontographical Society Monograph, 1-71.

MiLne EdwaRds, H. \& HAIME, J. 1851. Monographie des polypiers fossiles des terrains palaeozoïques. Archives $d u$ Muséum d'Histoire Naturelle 5, 1-502.

MORROW, J.R. 2007. Devonian shelf-to-slope facies and events, central Great Basin, Nevada and Utah, U.S.A. Subcommission on Devonian Stratigraphy SDS 2007 field trip guidebook. 93 pp. Unpublished, distributed in Las Vegas, Nevada.

MURPHY, M.A. 1977. Middle Devonian rocks of central Nevada, 190-199. In MURPHY, M.A., BERRY, W.B.N. \& SANDBERG, C.A. (eds) Western North America: Devonian. University of California, Riverside Campus Museum Contribution 4.

MuRPHY, M.A. \& GRONBERG, E.C. 1970. Stratigraphy and correlation of the Lower Nevada Group (Devonian) north and west of Eureka, Nevada. Geological Society of America Bulletin 81(1), 127-135. DOI 10.1130/0016-7606(1970)81[127:SACOTL]2.0.CO;2

OLIVER, W.A., JR. 1963. Redescription of three species of corals from the Lockport Dolomite in New York. United States Geological Survey Professional Paper 414-G, 1-9.

OLIVER, W.A., JR. 1976. Noncystimorph colonial rugose corals of the Onesquethaw and lower Cazenovia stages (Lower and Middle Devonian) in New York and adjacent areas. United States Geological Survey Professional Paper 869, 1-156.

OLIVER, W.A., JR. 1993. The Siphonophrentidae (rugose corals, Devonian) of eastern North America. In SANDO, W.J. (ed.) Shorter contributions to paleontology and stratigraphy, 1992. United States Geological Survey Bulletin 2024, B1-B32.

OLIVER, W.A., JR. \& GALLE, A. 1971. Rugose corals from the Upper Koněprusy Limestone (Lower Devonian) in Bohemia. Sborník geologických věd, Paleontologie 14, 35-106.

OLIVER, W.A., JR. \& SORAUF, J.E. 1981. Rugose coral biostratigraphy of the Devonian of New York and adjacent areas, 97-105. In OlIVER, W.A., JR. \& KLAPPER, G. (eds) Devonian Biostratigraphy of New York, 1. Text. Subcommission on Devonian Stratigraphy, Washington, D.C.

PEDDER, A.E.H. 1977. Systematics and biostratigraphic importance of the Lower Devonian rugose coral genus Exilifrons. Geological Survey of Canada, Report of Activities, Part B, Paper 77-1B, 173-180.

PEDDER, A.E.H. 1990. New genera of Middle Devonian rugose corals from the type Horn Plateau Reef, District of Mackenzie. Geological Survey of Canada Bulletin 396, 61-88. [date of imprint 1989]

PEDDER, A.E.H. 2002. New systematic and biostratigraphic data concerning the Breviphyllidae (Lower Devonian Rugosa) of Nevada. Coral Research Bulletin 7, 141-166.

PedDER, A.E.H. \& FEIST, R. 1998. Lower Devonian (Emsian) Rugosa of the Izarne Formation, Montagne Noire, France. Journal of Paleontology 72(6), 967-991.

PedDER, A.E.H. \& MCLEAN, R.A. 1982. Lower Devonian cystiphyllid corals from North America and eastern Australia with notes on the genus Utaratuia. Geologica et palaeontologica 16(1), 57-110.

PEDDER, A.E.H. \& MURPHY, M.A. 2004. Emsian (Lower Devonian) Rugosa of Nevada: Revision of systematics and stratigraphic ranges, and reassessment of faunal provincialism. Journal of Paleontology 78(5), 838-865. DOI 10.1666/0022-3360(2004)078<0838:ELDRON>2.0.CO;2 
PedDER, A.E.H. \& OliVER, W.A., JR. 1982. Stauromatidium and Stauromatidiidae, new genus and family of Upper Silurian and Lower Devonian rugose corals. Geological Survey of Canada Bulletin 352, 1-43.

PENECKE, K.A. 1894. Das Grazer Devon. Jahrbuch der Kaiserlichköniglichen geologischen Reichsanstalt 1893(43), 567-616.

PHILIP, G.M. \& PEDDER, A.E.H. 1968. Stratigraphical correlation of the principal Devonian limestone sequences of eastern Australia, 1025-1041. In OSWALD, D.H. (ed.) International symposium on the Devonian System, Calgary, 1968, Volume 2. Alberta Society of Petroleum Geologists, Calgary.

PHILLIPS, J. 1836. Illustrations of the geology of Yorkshire; Part 2; The Mountain Limestone district. 253 pp. Printed by Thomas Wilson, York, for the author \& John Murray, London.

PLUSQUELLEC, Y. 2007. Histoire naturelle des pleurodictyformes (Cnidaria Tabulata, Dévonien) du Massif armoricain et des régions Maghrebo-européenes principalement. Mémoires de la Société Géologique et Minéralogique de Bretagne 32, 1-138.

PlusquelleC, Y., BoumendJel, K., MORZADEC, P. \& PARIS, F. 1997. Les faunes dévoniennes d'Ougarta dans la paléogéographie des régions Maghrébo-europénnes. Les Annales de la Société Géologique du Nord (séries 2) 5, 123-128.

POTY, E. 1999. Famennian and Tournaisian recoveries of shallow water Rugosa following late Frasnian and late Strunian major crises, southern Belgium and surrounding areas, Hunan (South China) and the Omolon region (NE Siberia). Palaeogeography, Palaeoclimatology, Palaeoecology 154, 11-26.

DO1 10.1016/S0031-0182(99)00084-X

PROSH, E.C. 1995. Reply: Early Devonian age of the Detroit River Group, inferred from Arctic stromatoporoids. Canadian Journal of Earth Sciences 32(7), 1073-1077.

RADIG, F. 1962. Zur Stratigraphie des Devons in Asturien (Nord-Spanien). Geologische Rundschau 51(1), 249-267. DOI $10.1007 / \mathrm{BF} 01803238$

RODRÍGUEZ GARCÍA, S. 1978. Corales rugosos del Devónico de la sierra del Pedroso. Estudios Geologicos 34(3-6), 331-350.

RóżKOWSKA, M. 1953. Pachyphyllinae et Phillipsastraea du Frasnien de Pologne. Palaeontologia polonica 5, 1-89.

RUKHIN, L.B. 1938. Nizhnepaleozoiskie korally i stromatoporoidei verkhney chasti basseyna r. Kolymy. Materialy po Izucheniyu Kolymskogo-Indigirskogo Kraya, seriya 2, Geologiya i Geomorfologiya 10, 1-119.

SCHOUPPÉ, A.V. 1949. Die "Thamnophyllen" und ihre Beziehung zur Gruppe des "Cyathophyllum caespitosum". Palaeontographica A 97, 99-180.

SCHRÖDER, S. \& SOTO, F. 2003. Lower Devonian (Emsian) rugose corals from the Cantabrian Mountains, northern Spain. Acta palaeontologica polonica 48(4), 547-558.

SCOTESE, C.R. 1997. Continental drift. 79 pp. Paleomap Project, $7^{\text {th }}$ edition, Arlington.

SCOTESE, C.R. \& MCKERROW, W.S. 1990. Revised world maps and introduction, 1-21. In MCKERROW, W.S. \& SCOTESE, C.R. (eds) Palaeozoic, palaeogeography and biogeography. The Geological Society London Memoir 12.

SHIMER, H.W. \& SHROCK, R.R. 1944. Index fossils of North America. 1-837. The Technology Press Massachusetts Institute of Technology, Cambridge.

SiMPSON, G.B. 1900. Preliminary descriptions of new genera of Paleozoic rugose corals. Bulletin of the New York State Museum 39(8), 199-222.
SMITH, S. 1945. Upper Devonian corals of the Mackenzie River region, Canada. Geological Society of America Special Papers $59,1-126 \mathrm{pp}$.

SORAUF, J.E. 1972. Middle Devonian coral faunas (Rugosa) from Washington and Oregon. Journal of Paleontology 46(3), 426-439.

SORAUF, J.E. 1998. Frasnian (Upper Devonian) rugose corals from the Lime Creek and Shell Rock formations of Iowa. Bulletins of American Paleontology 113(355), 1-159.

SosHKINA, E.D. 1939. Verkhnedevonskie korally Rugosa Urala. Akademiya Nauk SSSR, Trudy Paleontologicheskogo Instituta 9(2), 1-88.

SOSHKINA, E.D. 1949. Devonskie korally Rugosa Urala. Akademiya Nauk SSSR, Trudy Paleontologicheskogo Instituta 15(4), 1-162.

Soshina, E.D., Dobrolyubova, T.A. \& KabaKovich, N.V. 1962. Podklass Tetracoralla. Chetyrekhluchevye korally (Rugosa), 286-356. In SOKOLOV, B.S. (ed.) Osnovy Paleontologii, tom 2, Gubki, Arkheotsiaty, Kishechnopolostnye, Cherni. Izdatel'stvo Akademii Nauk SSSR, Moskva.

SoTO, F. 1981. Synaptophyllum aus dem Unterdevon des Kantabrischen Gebirges (Nordspanien). Neues Jahrbuch für Geologie und Paläontologie, Monatshefte, Jahrgang 1981(2), 91-99.

STRUSZ, D.L. 1966. Spongophyllidae from the Devonian Garra formation, New South Wales. Palaeontology 9(4), 544-598.

StumM, E.C. 1937. The Lower Middle Devonian tetracorals of the Nevada limestone. Journal of Paleontology 11(5), 423-443.

STUMM, E.C. 1949. Revision of the families and genera of the Devonian tetracorals. Geological Society of America Memoir 40, $1-92$.

TALENT, J.A., GRATSIANOVA, R.T. \& YOLKIN, E.A. with a contribution from SHISHKINA, G.R. 2001. Latest Silurian (Pridoli) to Middle Devonian (Givetian) of the Asia-Australia hemisphere: rationalization of brachiopod taxa and faunal lists; stratigraphic correlation chart. Courier Forschungsinstitut Senckenberg 236, $1-221$.

ThORSTEInSSON, R. \& GLENISTER, B.F. 1963. Driftwood Bay, 585-596. In FORTIER, Y.O. et al. Geology of the north-central part of the Arctic Archipelago, Northwest Territories (Operation Franklin). Geological Survey of Canada Memoir 320.

ULiTinA, L.M. 2003. Rugozy, 199-268. In RozANOV, A.Y. (ed.) Paleontologiya Mongolii. Korally $i$ stromatoporoidei. Ordovik-Devon. Nauka, Moskva.

UyeNO, T.T., TELFORD, P.G. \& SANFORD, B.V. 1982. Devonian conodonts and stratigraphy of southwestern Ontario. Geological Survey of Canada Bulletin 332, 1-55.

VER STRAETEN, C.A. 2007. Basinwide stratigraphic synthesis and sequence stratigraphy, upper Pragian, Emsian and Eifelian stages (Lower to Middle Devonian), Appalachian Basin, 39-81. In BECKER, R.T. \& KIRCHGASSER, W.T. (eds) Devonian events and correlations. Geological Society, London, Special Publications 278.

WALLISER, O.H. 1985. Natural boundaries and Commission boundaries in the Devonian. Courier Forschungsinstitut Senckenberg 75, 401-408.

WANG CHENG-YUAN 2001. Supplements 2001, 435-462. In WedDIGE, K. (ed.) Devonian correlation table. Senckenbergiana lethaea $81(2)$.

WANG, H.C. (HONG-ZHEN) 1950. A revision of the Zoantharia Rugosa in the light of their minute skeletal structures. Philo- 
sophical Transactions of the Royal Society of London B(611), $234,175-246$.

WANG XUNLIAN 1987. The Middle and Late Devonian rugose corals of the Zhusilenghaierhan region, Nei Monggol, 93-106. In Zhu Hong, ZHENG ZhaOchang \& HE XINYI (eds) Palaeozoic biostratigraphy and tectonic evolution of the Alxa massif margin. Wuhan College of Geology Press, Wuhan. [in Chinese with English abstract]

WANG XUNLIAN \& WANG HONGZHEN 1987. The Middle and Late Devonian strata and the rugose coral palaeobiogeographical significance of Zhusileng Haierhan area, Neimongol. Geoscience 1, 311-326. [in Chinese with English abstract]

WANG ZHIPING 1985. Early and Middle Devonian Rugose coral biogeography of China. Earth Science - Journal of Wuhan College of Geology 10, 55-69.

WARREN, P.S. \& STELCK, C.R. 1950. Succession of Devonian faunas in western Canada. Transactions of the Royal Society of Canada 44 (section 4, series 3), 61-78.

WARREN, P.S. \& STELCK, C.R. 1956. Reference fossils of Canada, part 1, Devonian faunas of western Canada. Geological Association of Canada Special Paper 1, 1-15.
WEBSTER, C.L. 1889. Description of a new genus of corals from the Devonian rocks of Iowa. The American Naturalist 23(272), 710-712.

WEDEKIND, R. 1923. Die Gliederung des Mitteldevons auf Grund von Korallen. Gesellschaft zur Beförderung der gesamten Naturwissenschaften zu Marburg, Sitzungsberichte, Jahrgang 1922, 4, 24-35.

WedeKIND, R. 1924. Das Mitteldevon der Eifel. I. Teil. Die Tetrakorallen des unteren Mitteldevon. Schriften der Gesellschaft zur Beförderung der gesamten Naturwissenschaften zu Marburg 14(3), 1-93.

ZIEGLER, W. 2000. The Lower Eifelian boundary. Courier Forschungsinstitut Senckenberg 225, 27-36.

ZIEGLER,W. \& KLAPPER, G. 1985. Stages of the Devonian System. Episodes 8(2), 104-109.

ZHANG YAN 1985. Early Middle Devonian (Eifelian) brachiopods from Zhusilenghaierhan region, Western Nei Monggol. Acta palaeontologica sinica 24(2), 243-258. [in Chinese with English abstract]

ZHEN YONG-YI 1995. Late Emsian rugose corals of the Mount Podge area, Burdekin Basin, north Queensland. Alcheringa 19(3-4), 193-234.

\section{Appendix 1 - Rejected identifications of Synaptophyllum}

McLarens's (1959) and Oliver's (1976) exclusions from the genus are not repeated here.

Excluded species. - Macgeea (Synaptophyllum) heritschi Schouppé 1949 (p. 180, pl. 12, fig. 66) is a nomen nudum. The caption to figure 66 states that the illustrated, but unrecognisable coral is from the Grazer Palaeozoikum. Flügel \& Hubmann (1994, p. 22) added that it is from the Barrandeikalk at Schindelgraben. This suggests that it is uppermost Emsian or Eifelian.

Różkowska (1953, p. 16) emended Lang \& Smith's concept of Synaptophyllum (see discussion) by restricting it to species with large lateral (radiciform) processes. Thus, the early Frasnian species from the Holy Cross Mountains, Poland, named Synaptophyllum soshkinae by her (1953, p. 16, text-fig. 6, pl. 2, figs 1-4) has prominent lateral processes as well as a pipe of horseshoe dissepiments and phillipsastreid trabeculae. It is, in McLean's view (2005, p. 30), another species of Thamnophyllum.

The originally unprepared holotype of Synaptophyllum grabaui Fagerstrom (1961, p. 13, pl. 3, figs 11-14) is from the upper Emsian or lower Eifelian Amherstburg Formation on Detroit River, dividing Michigan from Ontario. Although after thin sectioning it remains unrecognisable, it is not a specimen of Synaptophyllum (Pedder \& Oliver 1982, p. 9, pl. 14, figs 10, 11). Fagerstrom's illustrated specimens assigned to the species are stauromatidiid corals, now referred to Fascidium trigemma (Davis 1887 , caption pl. 130, figs 1,2), from reef facies of the Amherstburg Formation in Bruce County, Ontario.

Synaptophyllum occidentale Sorauf (1972, p. 435, pl. 3, figs 5, 6; pl. 4, fig. 1) is based on a specimen from Limestone Hill in Pend Oreille County, northeastern Washington State. At the time of publication it was thought to have come from a sequence yielding Middle Devonian corals. Subsequently, Greenman et al. (1977) demonstrated faults and at least one major erosional break in the succession, and by means of conodonts established a Frasnian age for the topmost part (unit E) of it. The present author has collected twice on Limestone Hill, and has been shown photographs of corals from the area by the late G.O. Raasch (pers. comm., circa 1985). Rugosa from unit E include Mictophyllum semidilatum Smith, Frechastraea? sp., Pachyphyllum sp., Penenckiella metalinae Sorauf, Phillipsastrea nevadensis (Stumm) and Thamnophyllum colemanense (Warren). Synaptophyllum occidentale has not been recollected from its type area, but should almost certainly be added to the fauna of unit E. McLean \& Pedder (1987, p. 158) gave reasons for believing it to be a small, middle Frasnian species of Smithiphyllum with very few dissepiments and presepiments. The species is evidently rare on Limestone Hill, but is common in the western Canada sedimentary basin.

Synaptophyllum(?) oliveri Rodríguez García, 1978 (p. 344, pl. 3, figs 1-5), from a Pragian (S. Rodríguez, pers. comm., 2009) reef debris bed in the Sierra del Pedroso, southern Central Iberian zone, Spain, lacks the typical tabularial morphology of Synaptophyllum, and its minor septa are either absent, or appear only as peripheral spines.

Rejected transfers to Synaptophyllum. - Several early to mid twentieth century publications reported the presence of Synaptophyllum in Silurian beds of eastern North America. The species referred to Synaptophyllum in these works are either those originally named Lithostrotion harmodites Milne Edwards \& Haime (1851, p. 440, pl. 15, fig. 1, la), apparently introduced as a replacement for Lithodendron irregulare Castelnau (1843, p. 49, pl. 23, fig. 1; not Phillips 1836, p. 202, pl. 2, figs 14, 15), or Syringopora(?) multicaulis Hall (1852, p. 119, pl. 33, fig. 3a-g).

The interior morphology of the lectotype (designed holotype by Easton, 1957, p. 620) of "Lithostrotion" harmodites is unknown, but the exterior of the only known specimen certainly 
belonging to the species was redescribed and re-illustrated by Easton (1957, p. 620, pl. 71, fig. 4). Although Easton was aware that the label attached to the lectotype reads "Carboniferous of Indiana", he believed the coral to be a Silurian "species of Synaptophyllum very close, if not conspecific with $S$. multicaule (Billings)". In the absence of full knowledge of the interior morphology, the species is indeterminate. Nevertheless, since Easton was unequivocal that its septa are carinate, the species is not Synaptophyllum as the genus is currently diagnosed.

Ivanovskiy (1965, p. 83; 1978, p. 101) and most earlier workers interpreted Syringopora(?) multicaulis Hall as having dissepiments, and referred it to either Diphyphyllum or Entelophyllum. However, Hall's types (Oliver 1963, p. G-5, pl. 4, figs 1-7) lack both dissepiments and carinae, and are best regarded as a late, and in respect to their strongly elevated tabularium, somewhat atypical species of Palaeophyllum Billings (1858, p. 168; Hill 1981, p. F138). Oliver did not discuss the type stratigraphic occurrences of Palaeophyllum multicaule, given by Hall as "lower part of the Niagara limestone" at Lockport and Barre, western New York State, but Laub (1983, p. 28) indicated that they are likely in the upper Homerian (LoDuca \& Brett 1991) Gasport Formation. Bolton (1966, pl. 12, figs 1, 3) has illustrated the species from the undivided Lockport Formation at Thorold, southwestern Ontario.

Following Lang \& Smith's (1935) interpretation of the type species of Synaptophyllum as what today would be considered a phillipsastreid coral, Schouppé (1949, pp. 171, 172) employed Synaptophyllum as a subgenus of Macgeea Webster, 1889. Although used for fasciculate species, the only clearly specified criterion for recognition of Synaptophyllum as a subgenus by Schouppé was the presence of peripheral septal carination. Species transferred to Macgeea $(S$.) by Schouppé were Peneckiella nalivkini Soshkina (1939, p. 24, pl. 8, figs 68, 69) and $P$. spiralis Soshkina (1939, p. 28, pl. 10, figs 79, 80). Both are Frasnian species from the Urals, illustrated by line drawings which do not show trabecular structure. P. nalivkini appears to have uninterrupted peneckielloid dissepiments and may be Peneckiella strict sense, whereas $P$. spiralis appears to have a pipe of horseshoe dissepiments, indicating that it is likely to be a species of Thamnophyllum Penecke, 1894 (see also McLean 2005, pp. 31, 41).

Depasophyllum gansuense Ouyang (in Cao et al., 1983, p. 135, pl. 29, fig. 3a, b) is another species that has probably been erroneously transferred to Synaptophyllum. It was described from the southern side of the western Qinling fold belt, Gansu Province, in what later became the Gorizdronia profunda-Synaptophyllum gansuense Assemblage Zone (Cao 1987, p. 56; Cao \& Ouyang 1987, p. 192). Corals comprising the assemblage come from 220.7-422 m above the base of the Doushishan Formation. Palmatolepis glabra lepta and other conodonts, occurring with the corals, indicate a Late Devonian Famennian age (Li Jensing 1987, p. 80). This inadequately known coral resembles Synaptophyllum more than Depasophyllum, but most likely will prove to be another small species of Smithiphyllum with rare dissepiments. In China, Smithiphyllum is one of the rare coral genera to have survived (Liao 2002, fig. 1; 2004, p. 259), or to have reappeared as a lazarus genus (Poty 1999, fig. 3) after, the FrasnianFamennian extinction event.

Other revised identifications of Synaptophyllum. - A curiosity of both Lang's and Smith's precise systematics was their use of bra- ces (Lang \& Smith 1935, Lang 1938) or square brackets (Lang 1938, Smith 1945) for genomorphs. Justification for this unconventional procedure was most fully argued in Lang (1938), especially pages $156-159$, where genomorphs are defined as small groups of species having morphological characters, which were developed independently in one or several other lineages (see also Smith 1945, p. 7). Names for the genomorphs were taken from subjectively suppressed genera, such as Disphyllum (Synaptophyllum) in Lang (1938, p. 158) or Disphyllum (Synaptophyllum) in Smith (1945, pp. 22-24). These Synaptophyllum-named genomorphs were mistakenly used for species of Disphyllum de Fromentel, 1861, possessing horseshoe dissepiments and septal carinae. There is no indication that Lang or Smith ever regarded their genomorphs as subgenera. Thus, strictly, the Upper Devonian species Disphyllum (Synaptophyllum) densum and D. (S.) camselli erected by Smith $(1945$, p. 22, 23) are currently unacceptable species of Disphyllum, not subgenus Synaptophyllum. The former species has been removed to a previously named species of Peneckiella Soshkina (1939, p. 23) by McLean (2005, p. 42); the latter conforms to the diagnosis of Pantophyllum Lakhov (1982, p. 21).

Many collections from the area of Eaglesnest Pass, Jasper Park, western Canada have been examined. None contains Synaptophyllum. Warren \& Stelck's (1950, p. 68; 1956, pl. 20, fig. 9) identification and exterior illustration of a late Frasnian coral from this area as Synaptophyllum n. sp. was made before McLaren's (1959) revision of the genus was available. Warren \& Stelck's specimen is a species of Disphyllum de Fromentel, 1861.

With the help of the late C. H. Crickmay (pers. comm., 1961) and J. Craig (pers. comm., 1973) it has been possible to assess two of Crickmay's (1957, p. 4) listings of Synaptophyllum from the Upper Devonian "Grumbler Formation" on Hay River, District of Mackenzie, Canada. The reference to Synaptophyllum sp., occurring with Hexagonaria reticulata above Alexandra Falls, was based on a specimen of Peneckiella floydensis (Belanski, 1928, p. 176, pl. 12, fig. 1) sense of McLean (2005, p. 42), from the Upper Member of the Frasnian Twin Falls Formation. The reference to Synaptophyllum sp. n., in "12 feet of grey, fragmental and coralline limestone", was based on material of Smithiphyllum imbulliferum McLean \& Pedder (1987, p. 156, pl. 6, figs 1-5, 10, 11) from near the top of the Upper Member of the Twin Falls Formation.

The identification of Synaptophyllum sp. in the Blue Fiord Formation on Bathurst Island by D. J. McLaren (in Thorsteinsson \& Glenister 1963, p. 593) was based on probable lower Eifelian (costatus Zone) fragments of Dendrostella Glinski, 1957. One of these is illustrated in Fig. 5C.

Corals listed by Liberty \& Bolton (1971, p. 134) as Synaptophyllum arundinaceum (Billings) and $S$. simcoense (Billings) from bioherm facies (Formosa reef facies) of the Detroit River Group are assumed to be species of Acinophyllum. The identifications were taken from Best's unpublished 1953 thesis, and were based on Simpson's (1900), Shimer \& Shrock's (1944, p. 95) and other's flawed concept of Synaptophyllum.

An unprepared coral from the Columbus Limestone at Bellepoint, Delaware County, Ohio, has been illustrated by Babcock (1996, fig. 7-4.5) as Synaptophyllum simcoense (Billings). Although strictly unidentifiable, further study may show it to be a specimen of Synaptophyllum arundinaceum (Billings 1859), which is known from the Bellepoint Member of Ohio. It is less likely to be Acinophyllum simcoense (Billings 1859). 
The Emsian specimen identified as Synaptophyllum sp. (Ulitina 2003, p. 229, pl. R6, fig. 1a, b), from the sub-inversus Zone part of the Chulun Suite of Gobi Altay, Mongolia, is an unidentifiable corallite, about $22 \mathrm{~mm}$ in diameter. The transverse section reveals no minor septum, while the upside down longitudinal section appears to show two moderately large dissepiments.

\section{Appendix 2 - Stratigraphic and locality data}

Nevada Universal Transverse Mercator Grid references (UTMG) taken from 1986-90 editions of the cited 7.5 minute series topographic quadrangle maps; all references Zone 11. Unless otherwise stated, collections were made and identified by the author. Stratigraphic thicknesses measured in feet, converted to metres.

1990-18. Bartine Member, 92.4-98.8 m above base, and 45.7-50.3 m below top of member; lower F1 12 and upper gronbergi Zone. Ridge $580 \mathrm{~m}$ north-northwest of type Bartine exposure on Lone Mountain. UTMG 562970 m E 4383500 m N, Bartine Ranch Quadrangle. Holcocystis flexa (Stumm), Breviphrentis kirki Pedder, Romanophyllum? sp.

1990-31. Sadler Ranch Formation, 6.3-7.6 m above tongue of Oxyoke Canyon Sandstone, top of formation not exposed; patulus Zone. ROM III section on butte (Terrace Butte of Merriam, 1974, fig. 4) above old lake terrace, 680 m northwest of Romano Ranch house, eastern foot of southern Sulphur Spring Range. UTMG: 579365 m N 4414865 m N, Bailey Pass Quadrangle. Favosites sp., Alveolites sp., Lekanophyllum sp., Nardophyllum sp., Synaptophyllum romanense (Merriam), Romanophyllum paulyi sp. nov., Gasterocoma(?) bicaula Johnson \& Lane, Pandorinellina expansa Uyeno \& Mason, Belodella sp., Panderodus sp. Conodonts identified by T.T. Uyeno.

1994-8. Crinoidal unit, Sadler Ranch Formation, 15.3-15.4 m above base of unit exposure, and 8.3-8.4 m below top of unit; lower costatus Zone. TA II section $(\approx 630$ feet level) shown in Johnson et al. (1980, figs 2, 3), northern Antelope Range. UTMG $566350 \mathrm{~m}$ E $4345620 \mathrm{~m} \mathrm{~N}$, West of Bellevue Peak Quadrangle. Synaptophyllum romanense (Merriam).

1996-5. Same as 1990-31.

1996-31. Crinoidal unit, Sadler Ranch Formation, 4-5 m above base of unit exposure, and 6-7 m below top of unit exposure; lower costatus zone. TA Va section $(\approx 80$ feet level) shown in figs 2 , 3 of Johnson et al. (1980), northern Antelope Range. UTMG 566245 m E 4344805 m N, West of Bellevue Peak Quadrangle. Pseudomicroplasma? sp., Synaptophyllum romanense (Merriam), Xystriphyllum trojani sp. nov.

1996-32. Crinoidal unit, Sadler Ranch Formation, 0-0.5 m above base of unit exposure, and 10.5-11 m below top of unit exposure;
The report of an Emsian Synaptophyllum biostrome in the Moulin de Garel section, Montagne Noire (Schröder \& Soto 2003, pp. 547, 548), was based on preliminary field identifications of Breviphrentis species, as species of Synaptophyllum (F. Soto, pers. comm., 2009). These are the species described by Pedder (in Pedder \& Feist, 1998, p. 981) from the same Moulin de Garel biostrome (R. Feist, pers. comm. 2009).

lower costatus Zone. Same TA Va section as 1996-31 $\approx 71$ feet level). Pseudomicroplasma? sp. Synaptophyllum romanense (Merriam).

1996-33. Crinoidal unit, Sadler Ranch Formation, 1-2 m below top of unit exposure; lower costatus Zone. About $100 \mathrm{~m}$ north of same TA Va section as 1996-31 ( $\approx 100-103$ feet level). UTMG 566270 m E 4344900 m N. Pseudomicroplasma? sp., Synaptophyllum romanense (Merriam).

1996-34. Denay Limestone, debris flow, 4.6-4.9 m above exposed base of lower member; Pentamerella diverse community in upper costatus Zone of FI 15 (Johnson et al., 1980, tables 2, 15). Same TA Va Section as 1996-31 ( $\approx 121-122$ feet level). Mesophyllum sp., Sociophyllum sp., Xystriphyllum trojani sp. nov.

1996-36. Loose specimen free of matrix, collected by M.A. Murphy from debris flow near base of lower member of Denay Limestone; presumed lower costatus Zone. Between sections TA II and Va, northern Antelope Range (Johnson et al. 1980, fig. 2). Approximate UTMG 566290 m E 4344760 m N, West of Bellevue Peak Quadrangle. Xystriphyllum trojani sp. nov.

1997-7. Bartine Member, loose specimen collected $45.9 \mathrm{~m}$ above base, and $71.6 \mathrm{~m}$ below top of member; probably from gronbergi Zone. MDC II section, gully on right (east) side of Dry Creek, northern Roberts Mountains. UTMG 561620 m E 4422430 m N, Cooper Peak Quadrangle. Breviphyllid gen. undetermined (previously identified as Breviphyllum sp. A.).

1997-51. Bartine Member, talus collected near middle of member; presumed gronbergi Zone. About $540 \mathrm{~m}$ north-northwest of type Bartine Member exposure, Lone Mountain. UTMG 562955 m E $4383450 \mathrm{~m} \mathrm{~N}$, Bartine Ranch Quadrangle. Zonophyllum robertsense (Stumm), breviphyllid gen. undetermined.

1998-27. Same as 1990-31.

1999-11. Same as 1990-31.

GSC Locality 26441. Blue Fiord Formation, Eifelian (probably costatus Zone). Walker River below mouth of Ptarmigan Creek, 4 $\mathrm{km}$ inland from coast, Driftwood Bay area, eastern Bathurst Island. Approximate co-ordinates $75^{\circ} 58^{\prime} 20^{\prime \prime} \mathrm{N}$ Lat.; $97^{\circ} 48^{\prime} 00^{\prime \prime}$ W Long. Collected by B.F. Glenister, 1955. Dendrostella sp. 